\title{
NK Cell-Based Immunotherapy for Hematological Malignancies
}

\author{
Simona Sivori ${ }^{1,2}$, Raffaella Meazza ${ }^{3}$ (D), Concetta Quintarelli ${ }^{4,5}$, Simona Carlomagno ${ }^{1}$, \\ Mariella Della Chiesa ${ }^{1,2}$, Michela Falco ${ }^{6}$, Lorenzo Moretta ${ }^{7}$, Franco Locatelli ${ }^{4,8}$ and \\ Daniela Pende ${ }^{3, *}$ (i)
}

1 Department of Experimental Medicine, University of Genoa, 16132 Genoa, Italy; simona.sivori@unige.it (S.S); Simona.Carlomagno@unige.it (S.C.); Mariella.DellaChiesa@unige.it (M.D.C.)

2 Centre of Excellence for Biomedical Research, University of Genoa, 16132 Genoa, Italy

3 Department of Integrated Oncological Therapies, IRCCS Ospedale Policlinico San Martino, 16132 Genoa, Italy; raffaella.meazza@hsanmartino.it

4 Department of Hematology/Oncology, IRCCS Ospedale Pediatrico Bambino Gesù, 00165 Rome, Italy; concetta.quintarelli@opbg.net (C.Q.); franco.locatelli@opbg.net (F.L.)

5 Department of Clinical Medicine and Surgery, University of Naples Federico II, 80131 Naples, Italy

6 Integrated Department of Services and Laboratories, IRCCS Istituto Giannina Gaslini, 16147 Genoa, Italy; michelaemma.falco@gmail.com

7 Department of Immunology, IRCCS Ospedale Pediatrico Bambino Gesù, 00146 Rome, Italy; lorenzo.moretta@opbg.net

8 Department of Gynecology/Obstetrics and Pediatrics, Sapienza University, 00185 Rome, Italy

* Correspondence: daniela.pende@hsanmartino.it; Tel.: +39-010-555-8220

Received: 20 September 2019; Accepted: 11 October 2019; Published: 16 October 2019

\begin{abstract}
Natural killer (NK) lymphocytes are an integral component of the innate immune system and represent important effector cells in cancer immunotherapy, particularly in the control of hematological malignancies. Refined knowledge of NK cellular and molecular biology has fueled the interest in NK cell-based antitumor therapies, and recent efforts have been made to exploit the high potential of these cells in clinical practice. Infusion of high numbers of mature NK cells through the novel graft manipulation based on the selective depletion of T cells and CD19 ${ }^{+} \mathrm{B}$ cells has resulted into an improved outcome in children with acute leukemia given human leucocyte antigen (HLA)-haploidentical hematopoietic transplantation. Likewise, adoptive transfer of purified third-party NK cells showed promising results in patients with myeloid malignancies. Strategies based on the use of cytokines or monoclonal antibodies able to induce and optimize NK cell activation, persistence, and expansion also represent a novel field of investigation with remarkable perspectives of favorably impacting on outcome of patients with hematological neoplasia. In addition, preliminary results suggest that engineering of mature NK cells through chimeric antigen receptor (CAR) constructs deserve further investigation, with the goal of obtaining an "off-the-shelf" NK cell bank that may serve many different recipients for granting an efficient antileukemia activity.
\end{abstract}

Keywords: NK cells; receptors; acute leukemia; hematopoietic stem cell transplantation; HLA class I; killer immunoglobulin-like receptors; NK cell alloreactivity; cytokines; CAR-NK cells; immunotherapy

\section{Introduction}

Natural killer (NK) cells are cytotoxic and cytokine-producing components of innate lymphoid cells (ILCs), playing important roles in antiviral and antitumor defense [1,2]. ILCs represent a heterogeneous group of immune cells that are mainly localized at epithelial surfaces, where they maintain tissue homeostasis and quickly respond to pathogen invasion by mediating appropriate immune responses. 
They develop from a common lymphoid progenitor but, differently from $\mathrm{T}$ and B lymphocytes, lack the expression of antigen receptors encoded by rearranged genes. ILCs can be considered the innate counterparts of T cell subsets. In particular, NK cells represent the "cytotoxic ILC", whereas ILC1, ILC2, and ILC3 are considered as "helper ILCs" because they are noncytolytic and produce sets of cytokines unique for each subset. Both NK cells and helper ILC1 share the expression of Tbet transcription factor, encoded by the $T b x 21$ gene that is involved in IFN- $\gamma$ production, but differ in eomesodermin (Eomes) transcription factor expression. Indeed, NK cells are Tbet ${ }^{+}$Eomes $^{+}$while ILC1 are Tbet $^{+}$Eomes $^{-}[3,4]$. Recent advances of our knowledge underline a certain degree of plasticity among the various ILC subsets, mainly by the influence of tissue microenvironment $[2,5]$.

NK cells are equipped with a wide array of germline-encoded inhibitory and activating receptors, which can be engaged by specific ligands expressed on various cells at the immunological synapse. NK cell function is a finely tuned balance between activating and inhibitory signaling transmitted by these receptors. NK cells preserve tolerance towards surrounding healthy cells, mainly through inhibitory receptors recognizing self-major histocompatibility complex (MHC) class I molecules. In humans, they are represented by killer immunoglobulin-like receptors (KIRs) and CD94:natural killer group 2A (NKG2A), specific for classical and nonclassical HLA class I molecules, respectively. In the process of NK cell "education", the strength of these inhibitory receptor/ligand interactions positively correlates with the functional potential of NK cells [6]. Responsible for the "on" signal are several triggering receptors, including natural cytotoxicity receptors (NCRs) and natural killer group 2D (NKG2D), whose ligands are mainly stress-inducible molecules. NK cells can attack viral infected and cancer cells that have downregulated HLA class I molecules through "missing self recognition", and/or have overexpressed ligands of the activating receptors leading to "induced self-recognition". In peripheral blood (PB), two main NK cell subsets have been identified. A minority is represented by $\mathrm{CD} 56^{\text {bright }} \mathrm{CD} 16^{-} \mathrm{NK}$ cells, characterized by the expression of CD94:NKG2A and not KIR, and considered the immature subset. Most PB-NK cells are CD56 ${ }^{\mathrm{dim}} \mathrm{CD} 16^{+}$and are extremely diversified in terms of KIRs and CD94:NKG2A phenotype, displaying higher cytotoxic potential [7].

The potent and rapid cytotoxicity exerted by NK cells makes them important and robust effectors in antitumor immunotherapy. NK cells can respond to different types of chemokines released in tumor sites and can release chemotactic high mobility group box 1 (HMGB1) capable of amplifying the antitumor response by attracting additional NK cells at the tumor site [8]. Moreover, preclinical studies and clinical trials have demonstrated the nontoxicity and efficacy of the use of allogeneic NK cells against various hematological malignancies [9-12]. Although acute myeloid leukemia (AML) patients have been more investigated in NK cell-based approaches, also chronic myeloid leukemia (CML) patients can be considered possible candidates, since recent clinical studies, such as IMMUNOSTIM [13] and EURO-SKI [14], have shown a positive correlation between higher NK cell numbers after imatinib discontinuation and molecular relapse-free survival.

In this review, we first describe the NK cell biology with the various receptor/ligand interactions governing their capability to attack malignant cells, particularly of hematological origin, and then the different immunotherapeutic approaches employing autologous or allogeneic NK cells, in transplantation and non-transplantation setting, either un-activated or potentiated by different systems including cell engineering.

\section{NK Cell Receptors}

\subsection{HLA-Specific NK Receptors}

Two main types of NK cell receptors, capable of recognizing HLA class I molecules, are KIRs and CD94:NKG2 heterodimers, whose expression is mainly confined to NK cells and small subsets of T cells [15]. In addition, leukocyte immunoglobulin like receptor B1 (LILRB1) (also named ILT-2, LIR-1, or CD85j) is not only present on NK and T but also, at high surface density, on B and myeloid cells. 
LILRB1, interacting with conserved $\alpha 3$ domain and $\beta 2$ microglobulin, recognizes a broad spectrum of classical and nonclassical HLA class I molecules [16].

KIRs are type I molecules, including both inhibitory (iKIR) and activating (aKIR) receptors [15,17]. Their nomenclature reflects their structure and function: KIR2D and KIR3D indicate two or three extracellular domains, followed by L (long) or S (short), related to the cytoplasmic tail of iKIR or aKIR, respectively [18]. Inhibitory KIRs have a long cytoplasmic tail that contains immunoreceptor tyrosine-based inhibitory motifs (ITIM), able to transduce an inhibitory signal through the recruitment of tyrosine phosphatases. Conversely, aKIRs are characterized by short cytoplasmic tails lacking ITIM motifs and display a positively charged amino acidic residue (Lys) in the transmembrane region, which mediates the association with KARAP/DAP12, a molecule containing immunoreceptor tyrosine-based activating motifs (ITAM) [19-21]. An exception is represented by KIR2DL4, a receptor characterized by both a long cytoplasmic tail, including a single ITIM motif, and a charged amino acid (Arg) in the transmembrane region, allowing its association with $\gamma$ chain of FceRI. Notably, in resting NK cells, engagement of KIR2DL4 results in strong cytokine (IFN- $\gamma$ ) production [22].

The polygenic and polymorphic KIR gene family maps on chromosome 19p13.4 and consists of 13 genes and 2 pseudogenes. KIR genes are organized in haplotypes and the two main groups, varying for both type and number of gene content, are termed A and B. Generally, group A haplotypes comprise a fixed number of genes, most of which encoding iKIR (KIR2DL1, KIR2DL3, KIR3DL1, and KIR3DL2) with only one aKIR (KIR2DS4), and display high degree of allelic polymorphism. Conversely, group B haplotypes are characterized by a greater gene content diversity, including a variable number of aKIR (KIR2DS1, KIR2DS2, KIR2DS3, KIR2DS4, KIR2DS5, and KIR3DS1), and by low allelic polymorphism [23]. A recombination hot spot, located between KIR3DP1 and KIR2DL4, splits the haplotypes into centromeric (Cen) and telomeric (Tel) regions [24]. Various combinations of Cen and Tel regions can be created, and while KIR A haplotypes are composed by Cen-A/Tel-A, all the others correspond to KIR B haplotypes.

The four main iKIRs are specific for epitopes shared by distinct groups of HLA class I allotypes, also named KIR-ligands (KIR-L). The dimorphism at position 80 defines two mutually exclusive HLA-C epitopes, differentially recognized by KIR2DL1 and KIR2DL2/L3. In particular, KIR2DL1 recognizes HLA-C ${ }^{\text {K80 }}$ allotypes (HLA-C2 epitope), while KIR2DL2/L3 recognize HLA-C ${ }^{\text {N80 }}$ allotypes (HLA-C1 epitope). In addition, KIR3DL1 is specific for HLA-B or HLA-A molecules sharing the Bw4 public epitope (Bw $4^{\mathrm{I} 80}$ or Bw $4^{\mathrm{T} 80}$ ), and KIR3DL2 binds HLA-A ${ }^{*} 03$ and $-\mathrm{A}^{*} 11$ allotypes [15]. Regarding aKIR, except for KIR2DS1 recognizing HLA-C2 as its inhibitory counterpart (KIR2DL1) [25], their ligand recognition remained elusive for a long time. The actual view of KIR/KIR-L interactions appears more and more complex, taking into consideration the KIR allelic polymorphism and the diverse repertoire of peptides bound to the polymorphic HLA class I molecules. Updated data have been recently reviewed [26].

Other receptors are represented by the inhibitory CD94:NKG2A and the activating CD94:NKG2C heterodimers, composed by type II proteins belonging to the C-type lectin superfamily, which recognize the non-classical HLA class I molecule HLA-E [27]. HLA-E is characterized by limited polymorphism and binds a restricted set of peptides, mainly derived from the leader sequences (from -22 to -14 residues) of HLA-A, $-\mathrm{B}$, or -C molecules. For this reason, CD94:NKG2A is considered a sensor of the overall amount of HLA class I expressed on the cell surface. The M/T dimorphism at position -21 of the leader sequence of HLA-B has been described as impacting the CD94:NKG2A/HLA-E interaction. Indeed, in -21M HLA-B individuals, higher HLA-E expression and more efficient NKG2A ${ }^{+}$ NK cells have been detected [28]. This feature has been shown relevant in NK cell activity against AML blasts, which display a low HLA-E expression. Studying a cohort of AML patients receiving histamine dihydrochloride and low dose interleukin (IL)-2 to prevent relapse, Hallner et al. found that patients carrying at least one -21M HLA-B had a better clinical outcome [29].

Among different individuals, a great heterogeneity of PB-NK cell phenotypes, particularly within the CD56 ${ }^{\text {dim }}$ subset, can be observed. This diversity is primarily due to the high polymorphism 
of KIR and HLA class I genes, which segregate independently, leading to diverse compound genotypes [17]. In addition, the clonal distribution of KIRs and CD94:NKG2A, which are epigenetically regulated, creates highly stochastic repertoires of self-tolerant NK cells, following the rules of NK cell "education" [6]. Thus, each competent NK cell, expressing at least an inhibitory receptor specific for self-HLA, can attack unhealthy cells that have downregulated HLA class I molecules through "missing self" recognition. By the same mechanism, NK cells can be alloreactive when expressing only "educated" inhibitory KIR(s) that are not engaged by the HLA class I molecules (i.e., KIR-L) present on allogeneic cells. This situation frequently occurs in HLA-haploidentical hematopoietic stem cell transplantation (haplo-HSCT), when a KIR/KIR-L mismatch in graft-versus-host (GvH) direction is present. Genetically defined by donor KIR gene profile and donor/recipient KIR-L, the actual size of the alloreactive NK cell subset can greatly differ among different donors [11].

\subsection{Non-HLA Specific Activating NK Receptors}

One of the earliest functions described for NK cells was the capability to perform antibody dependent cell-mediated cytotoxicity (ADCC) through the engagement of CD16, the low affinity receptor for fragment crystallizable (Fc) of IgG (Fc $\gamma$ RIIIa) [30]. This activating receptor can be exploited to potentiate the antitumor NK cell activity in adoptive immunotherapy by the use of IgG antibodies recognizing tumor-associated antigens, bispecific, or trispecific killer engagers (BiKEs and TriKEs, respectively), as described in 4.2 paragraph.

In addition, NK cells express a set of triggering receptors and coreceptors that deliver the "on" signal upon interaction with specific ligands on tumor target cells. Major NK cell receptors are the natural cytotoxicity receptors (NCRs) [31], type I molecules of the Ig family, consisting of three members: NKp46, NKp30, and NKp44 [32-36]. While NKp46 and NKp30 are expressed on virtually all resting NK cells, NKp44 is acquired upon activation. NCR transmembrane domains contain a positively charged amino acid, allowing the association with ITAM-bearing adaptor proteins, namely FceRI $\gamma$

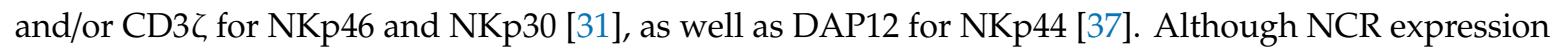
was considered confined to NK cells, more recently, one or another NCR has been also detected on subsets of ILC $[2,38,39]$. Notably, upon appropriate culture conditions, NKp30 is inducible on $\gamma \delta \mathrm{T}$ cells or $\mathrm{CD}^{+} \alpha \beta \mathrm{T}$ cells that acquire a "gain of function", and thus, an enhanced leukemia recognition and killing [40-42]. Functional evidences that NCRs, especially NKp46, play a primary role in leukemia recognition and killing induction have been provided [43]. Although many NCR ligands (NCR-Ls) have been characterized, the panel of the membrane bound molecules, possibly overexpressed in hematological malignancies, appears incomplete [44,45]. In this regard, relevant surface molecules are B7-H6 and a splice variant of mixed-lineage leukemia 5 (21spe-MLL5), identified as NKp30-L and NKp44-L, respectively [46,47]. Importantly, the interaction between NKp44 and a subset of HLA-DP molecules (i.e., HLA-DP401) has been recently proven to trigger functional NK cell responses [48]. Other NCR-Ls are represented by nuclear antigens that can reach the plasma membrane during tumor transformation and can be expressed in exosomes by tumor cells: Proliferating cell nuclear antigen (PCNA), recognized by NKp44, and HLA-B-associated transcript 3 (BAT3), also known as BCL2-associated athanogene 6 (BAG6), by NKp30 [49,50]. Several soluble NCR-Ls have been identified, including complement factor $\mathrm{P}(\mathrm{CFP})$ recognized by NKp46, platelet-derived growth factor (PDGF)-DD and nidogen-1 by NKp44, in addition to soluble forms of the NKp30-L BAG6 and B7-H6 [51-54]. Soluble NCR-Ls are studied as biomarkers for cancer patients. Regarding hematological malignancies, in chronic lymphocytic leukemia (CLL) patients, high plasma levels of soluble BAG6 have been associated with advanced disease stages; in contrast, NK cells were activated by BAG6 presented on the surface of exosomes [55]. The shedding of NCR-Ls by neoplastic cells can be envisaged as a tumor immune escape mechanism; indeed, it can induce receptor surface downmodulation with consequent NK cell dysfunction. The observation of NK cells with $\mathrm{NCR}^{\text {dull }}$ phenotype [56] has been described in AML and CLL patients [57-59]. Moreover, impairment in NCR expression and function can be induced by hypoxia or additional soluble factors present in the tumor microenvironment, including 
indoleamine 2,3-dioxygenase (IDO), transforming growth factor-beta (TGF- $\beta$ ), and prostaglandin E2 (PGE2) [60-62]. Indeed, in patients affected by solid and hematologic tumors, $\mathrm{NCR}^{\text {dull }} \mathrm{NK}$ cells can be detected in peripheral blood but particularly in the tumor site [63]. Moreover, TGF- $\beta$ contributes in the plasticity of group 1 ILCs, driving the conversion of NK cells into ILC1. This represents a mechanism of immune evasion in the tumor microenvironment [64].

Another major NK-activating receptor is the NKG2D homodimer, a type II and C-type lectin-like molecule, which is expressed on all NK and cytotoxic T lymphocytes, mainly $\gamma \delta \mathrm{T}$ cells and CD8 ${ }^{+}$ $\alpha \beta T$ cells. Upon receptor engagement, human NKG2D transduces an activation signal via the associated transmembrane adaptor protein DAP10. Multiple NKG2D ligands (NKG2D-Ls) have been characterized and are represented by MHC class I chain-related protein A/B (MICA/B) and UL16 binding proteins (ULBP)1-6 [65]. It's well known that their expression on the cell membrane is induced upon stress and malignant transformation. MICA/B are transmembrane molecules and have been mainly described on epithelial tumors and melanoma [66,67]. ULBP1/3/6 are GPI-anchored molecules and ULBP4/5 are transmembrane molecules, whereas ULBP2 can be in both forms. NKG2D-L expression on primary leukemias and the consequent involvement of NKG2D in NK cell-mediated target recognition has been documented $[43,68,69]$. In leukemia patients, the levels of NKG2D-Ls, as surface expressed and/or in soluble form, have been correlated with NKG2D downregulation and reduced NK cell function and clinical data, underlying the relevance of NKG2D-mediated tumor immunosurveillance and escape [68].

NK cells are also equipped with costimulatory receptors, which can collaborate with NCR and NKG2D, enhancing the activating signaling and NK cell function. They include DNAM-1 [70], 2B4 (CD244) [71], NTB-A [72], CD59 [73], and NKp80 [74]. Relevant for antileukemia activity, DNAX accessory molecule 1 (DNAM-1) (CD226) can recognize the specific ligands poliovirus receptor (PVR) (CD155) and Nectin-2 (CD112), found to be expressed on various acute leukemias [43,75]. Belonging to the signaling lymphocytic activation molecule (SLAM) family receptors, NK-T-B-antigen (NTB-A) displays homophilic interaction like the other members, while 2B4 recognizes CD48, exclusively present on hematopoietic cells. Upon receptor engagement, the ITSMs in their cytoplasmic tail become phosphorylated and associate with SLAM associated protein (SAP), which in turn activates downstream signaling pathways resulting in NK cell activation. High levels of CD48 and NTB-A are expressed by Epstein-Barr virus (EBV) infected B cells and lymphomas [76]. Conversely, a downregulation of these molecules is often observed on acute leukemia cells [43].

In addition, NK cells can be activated by the recognition of bacterial or viral products via toll-like receptors (TLRs) [77,78].

\subsection{Inhibitory Checkpoints Expressed on Human NK Cells}

In addition to the HLA class I specific inhibitory receptors (iKIRs and NKG2A), additional inhibitory checkpoints, responsible for maintaining the immune cell homeostasis, can be expressed on human NK cells. They include programmed death-1 (PD-1), T-cell Ig and ITIM domains (TIGIT), CD96, and T-cell Ig and mucin domain-containing protein 3 (TIM-3) [79,80]. In pathological conditions, such as hematological malignancies, high expression of ligands for inhibitory checkpoints have been associated with poor prognosis [81]. Indeed, the tumor microenvironment can induce the de novo expression of some of these immune checkpoints on tumor-associated NK cells, thus facilitating tumor immune escape.

PD-1 (CD279 or PDCD1) is a major checkpoint expressed by NK cells [82,83]. It binds to PD-L1 (CD274, B7-H1, or PDCD1LG1) or PD-L2 (CD273, B7-DC, or PDCD1LG2), with the highest affinity for PD-L2. PD-L1 expression is usually low on healthy tissues [84], but is upregulated on various tumor types upon exposure to inflammatory conditions (e.g., IFN- $\gamma$ ) or following activation of key oncogenic pathways involving phosphoinositide 3-kinase (PI3K) or mitogen-activated protein kinase (MAPK). On the other hand, PD-L2 is expressed by antigen presenting cells and by certain solid tumors. The molecular mechanisms regulating the expression of PD-1 on human NK cells have not 
been defined so far. However, it is conceivable that signals delivered by cells and/or soluble factors present in the tumor microenvironment may play an important role [85].

The TIGIT and CD96/Tactile immune checkpoints [86,87] compete with the activating receptor DNAM-1 for binding to PVR and Nectin-2, molecules that are usually upregulated in tumor cells [75]. A recent report has suggested that TIGIT targeting with specific mAbs may unleash $\mathrm{T}$ and NK cell antitumor activity and prevent NK cell exhaustion [88].

Other inhibitory checkpoints that may be expressed by NK cells are lymphocyte-activation gene 3 (LAG-3) and TIM-3. While blockade of TIM-3 has been shown to increase NK cell cytotoxicity in preclinical models [89], the effect of LAG-3 on NK cell function is still unclear and requires further investigation [90,91]. The main ligand of TIM-3 is galectin-9 [92], but other ligands have been identified, such as phospatidyl serine (PtdSer) [93], HMGB1 [94], and carcinoembryonic antigen-related cell adhesion molecule 1 (CEACAM1) [95].

NKRP1A (CD161), a C-type lectin-like inhibitory receptor that recognizes lectin-like transcript 1 (LLT1), can be considered a putative checkpoint receptor. Indeed, since LLT1 is expressed by different tumors, including B-cell non-Hodgkin's lymphomas (NHLs) [96], this receptor/ligand pair may play a role in tumor escape from NK cell control. Moreover, blocking NKRP1A/LLT1 interaction increases NK cell-mediated secretion of IFN- $\gamma$ and killing of NHL cell lines. Thus, the use of anti-LLT1 blocking mAbs may improve tumor immunosurveillance and also enhance the efficacy of anti-CD20-based immunotherapy strategies [97]. Immunoregulatory cytokines in the microenvironment can modulate NKRP1A expression and consequently NK cell function. IL-12 induces upregulation of NKRP1A in NK cells, leading to a strong inhibition of the cytolytic activity mediated by CD16 or NKp46 [98]. Conversely, IL-2 reduces NKRP1A expression in NK cells, possibly contributing to enhanced killing activity [99].

\section{NK Cells in Haploidentical HSCT and Adoptive Immunotherapy}

\subsection{T Cell-Depleted and T Cell-Replete HSCT}

Allogeneic HSCT is a life-saving treatment for patients affected by high-risk malignant hematologic disorders. However, only $25 \%$ of patients who need an allograft have an HLA-identical sibling available as donor. Thus, alternative donors and sources of hematopoietic stem cells (HSC) can be matched to unrelated volunteers, unrelated umbilical cord blood (UCB), and HLA-haploidentical relatives (i.e., a family member sharing one HLA-haplotype with the recipient) [100]. Haplo-HSCT offers an immediate option to almost all patients in need of an allograft. However, because of multiple HLA class I and II disparities between donor and recipient, bidirectional alloreactivity to incompatible HLA molecules can cause important clinical complications, including graft failure and the incidence of both acute and chronic graft-vs-host disease (GvHD). Donor-derived T cells are the most responsible for the occurrence of severe GvHD, and different T-cell depletion strategies or pharmacological immunosuppressive treatments have been employed [9-11].

Pioneering clinical studies by the Perugia group rendered successful haplo-HSCT, through the use of intense conditioning regimen preventing graft rejection, and inoculum of "megadoses" of highly purified CD34 ${ }^{+}$cells, thus avoiding GvHD [101]. Ruggeri et al. demonstrated, in adult AML patients, an efficient post-transplant NK cell recovery and protective graft-vs-leukemia $(\mathrm{GvL})$ effects mediated by alloreactive NK cells, in the absence of GvHD. Indeed, transplantation from donors characterized by alloreactive NK cells was associated with a lower incidence of relapse and an improvement of the overall survival in AML adult patients [102-104]. The beneficial effect of donor NK alloreactivity was also observed in children with high-risk acute lymphoid leukemia (ALL) showing $70 \%$ versus $35 \%$ survival rate in the presence versus absence of NK alloreactivity, respectively [11]. The first lymphocyte population that reconstitutes after HSCT is represented by NK cells displaying an immature phenotype, and several months are necessary for their acquisition of full phenotypic and functional maturation [105]. In pediatric leukemia patients undergoing T cell-depleted haplo-HSCT, 
donor-derived alloreactive NK cells displaying antileukemia activity were generated, appeared in PB after 2-3 months, and could persist for years in the recipient. Moreover, a positive role of KIR2DS1 ${ }^{+}$ NK cells derived from HLA-C1/C2 donors was also demonstrated in the recognition and killing of HLA-C2/C2 leukemia cells [106]. However, a general problem occurring in T cell-depleted haplo-HSCT is the delayed immune recovery, increasing the risk for patients of life-threatening opportunistic infections [100,104].

In recent years, a T cell-replete haplo-HSCT was developed by the use of an unmanipulated graft and post-transplant high-dose cyclophosphamide (PTCy) administration, followed by other immunosuppressive drugs, to prevent GvHD. The use of PTCy aims to selectively eliminate alloreactive $\mathrm{T}$ cells rapidly proliferating in response to the recipient alloantigens. Thus, in this transplantation setting, an accelerate immune reconstitution by the maintenance of a broad repertoire of nonalloreactive $\mathrm{T}$ lymphocytes, potentially active against post-transplant infections, might be achieved [107]. Morever, Russo et al. reported that donor-derived NK cells, proliferating for the high systemic levels of IL-15, become sensitive to Cy-mediated killing. Thus, early elimination of all mature NK cells, including the alloreactive subset, has been documented. The delayed recovery of mature NK cells through the differentiation from precursors might result in an impaired NK-mediated antileukemic potential. Consequently, no evidence of a beneficial effect of donor NK alloreactivity on the outcome of patients was observed [108]. In addition, in a retrospective multicenter analysis, KIR-L mismatching was associated with a worse outcome in leukemia patients receiving haplo-HSCT and PTCy when peripheral blood stem cells (PBSC) were used as graft cell source [109].

\subsection{Adoptive NK Cell Immunotherapy within Transplant Setting}

In both $\mathrm{CD}_{3} 4^{+}$and PTCy haplo-HSCT, the delayed recovery of mature NK cells can impair their GvL effect and protection against viral infections. To circumvent this problem, adoptive immunotherapy approaches with highly purified donor-derived NK cells have been largely investigated in different transplantation settings. Several clinical trials are currently active and ongoing. Although the efficacy appeared limited to a minority of patients, NK-donor lymphocyte infusions (NK-DLI) prior to or post-HSCT were shown to be feasible without severe side effects [110-112].

In a pilot study on AML patients, donor NK cells were infused after haplo-HSCT, to consolidate incomplete engraftment [113]. Indeed, purified NK cells, preferentially recognizing hematopoietic host cells, promoted engraftment without inducing GvHD. The safety and feasibility of the adoptive transfer of allogeneic NK cells were further confirmed in a phase II study, but NK-DLI had no apparent effect on graft failure or relapse incidence [114].

In a phase I/II trial, in which AML patients underwent haplo-HSCT in combination with early transfer of NK cells, a two year overall survival rate of $37 \%$ was observed, suggesting that adoptively transferred NK cells possibly contribute to long-term remission in patients with refractory AML [115].

The favorable cytokine environment, with high systemic levels of IL-15, in patients immediately after haplo-HSCT with PTCy [108], provided the rationale for NK-DLI to reduce relapse incidence and viral infections. Clinical trials based on the infusion of donor NK cells after haplo-HSCT and PTCy have been started [116,117]. In a phase I study for high-risk myeloid malignancies, high doses of ex-vivo expanded donor-derived NK cells infusions significantly improved NK cell function and may be effective to prevent leukemia relapse with no major toxicity [117].

Notably, it should be considered that, in addition to the characteristics of the different transplantation settings, several NK cell-related variables, including their preparation (either unstimulated or ex-vivo activated/expanded), dose, timing of the infusion, and presence of NK cell alloreactivity, may also influence clinical responses [118,119]. 


\subsection{Haploidentical HSCT after CD3/CD19 or TCR $\alpha \beta / C D 19$ Depletion}

New graft manipulations have been employed with the aim to infuse NK cells together with HSC [120]. In haplo-HSCT, depletion of $\mathrm{CD}^{+}{ }^{+} \mathrm{CD} 19^{+}$cells, instead of $\mathrm{CD} 34^{+}$cell selection, leads to a better engraftment and immune reconstitution [121,122]. This procedure allows the elimination of $\mathrm{T}$ cells, responsible for GvHD, and $\mathrm{CD} 19^{+} \mathrm{B}$ cells, to prevent post-transplant EBV-related lymphoproliferative disorders. This graft manipulation has been applied for both children and adult acute leukemia patients. Although promising clinical results have been reported, GvHD incidence was quite high due to different levels of $\mathrm{T}$ cell depletion, requiring the development of more efficient procedures. A further improvement has been represented by the approach based on selective TCR $\alpha \beta$ T and CD19 B cell depletion from mobilized PBSC $[123,124]$. This refined procedure allows the accurate removal of $\alpha \beta T$ cells, responsible for GvHD, and the infusion of a graft enriched for HSC and also containing other cell types, including mature NK cells and $\gamma \delta$ T lymphocytes (NCT01810120). The presence of these mature effectors can favor the engraftment and reduce the risk of infections and leukemia recurrence. Thus, in $\alpha \beta$ T and B cell-depleted haplo-HSCT, high numbers (about 20-40 millions/kg of recipient body weight) of donor mature NK cells, including alloreactive populations, are immediately available and can fully display their activity because of the absence of pharmacological GvHD prophylaxis. NK cells may promptly exert their antileukemia and GvHD-preventing effects in the 6-8 weeks after transplantation, before the emergence of $\mathrm{KIR}^{+} \mathrm{NK}$ cells differentiated from $\mathrm{CD} 34^{+}$precursors. Transplanted patients also benefit from many $\gamma \delta \mathrm{T}$ cells, which contribute to anti-infectious and possibly to antileukemia activities [125]. Importantly, the clinical outcomes of pediatric leukemia patients receiving $\alpha \beta \mathrm{T}$ and B cell-depleted haplo-HSCT were very good, showing high leukemia-free survival (LFS, $71 \%$ and $68 \%$ in high risk ALL and AML, respectively) and low risk of GvHD [126]. In this cohort, the donor (either mother or father of the patient) was mainly chosen according to immunological criteria, giving priority to NK alloreactivity, KIR B/x genotype, higher B-content score, and larger size of alloreactive NK cell subset [106,127-129] (Figure 1). In addition, donor/recipient HCMV serology, donor age, donor/recipient body weight, presence of KIR2DS1 in HLA-C1 ${ }^{+}$donor and HLA-C2 ${ }^{+}$recipients, higher percentage of NK and $\gamma \delta \mathrm{T}$ lymphocytes, higher expression of NKp46, and presence of NKG2C were also evaluated $[11,43,106,130]$. Recently, the European Society for Blood and Marrow Transplantation (EBMT) elaborated consensus recommendations for donor selection in haplo-HSCT [131]. 
A

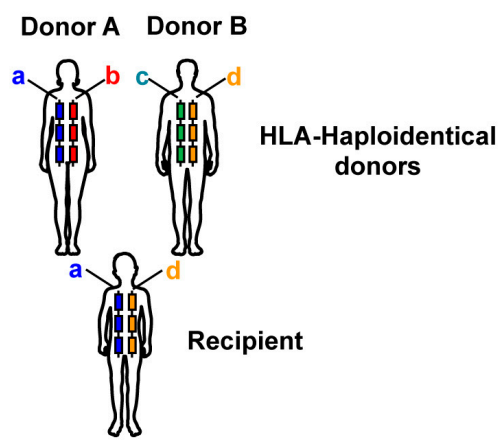

C
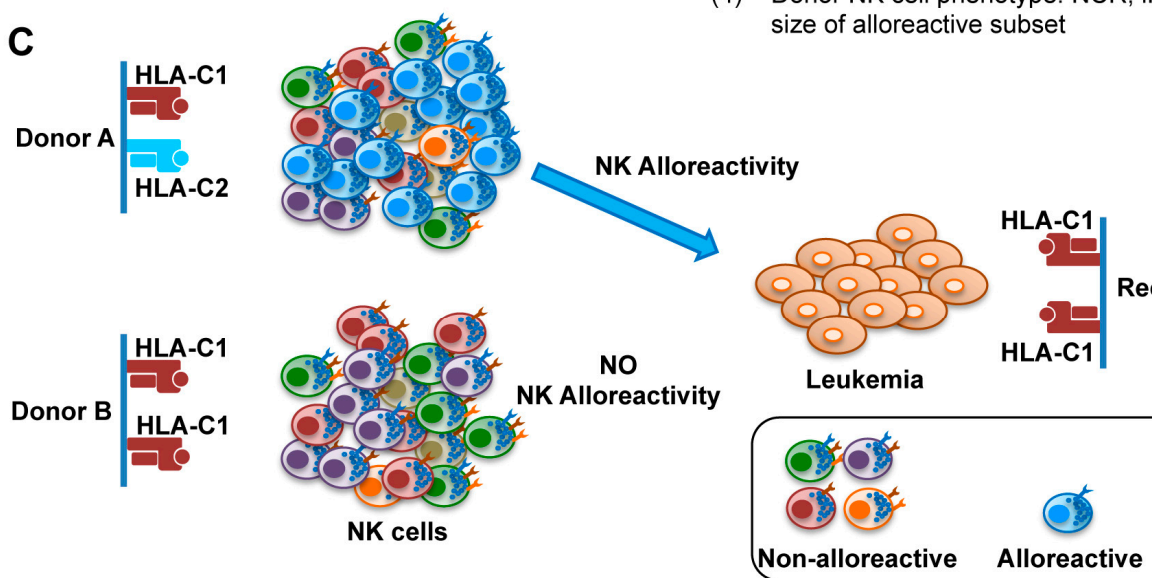

Figure 1. Donor selection in haploidentical-hematopoietic stem cell transplantation (haplo-HSCT). (A) Alternative human leucocyte antigen (HLA)-haploidentical donors (e.g., both parents of a pediatric patient) can be available for haplo-HSCT to cure leukemia patients. (B) Various analyses can be performed to define the possible donor natural killer (NK) alloreactivity, killer immunoglobulin-like receptor (KIR) genotype, and NK cell phenotypic repertoire to guide the choice for selecting the optimal donor. (C) A schematic representation of donor A and donor B NK cell repertoires, characterized by presence or absence of NK alloreactivity, respectively. Only donor A has alloreactive NK cells, namely "educated" NK cells expressing only KIR2DL1, the inhibitory KIR (iKIR) specific for HLA-C2 epitope, present in the donor and absent in the recipient. The alloreactive NK cell subset of donor A will be highly efficient in leukemia killing, indicating that donor A can be better than donor B.

\subsection{Adoptive NK Cell Immunotherapy in Nontransplant Setting}

Antileukemia activity of the adoptive transfer of NK cells from haploidentical donors in nontransplant settings has been also explored. In the first study by Miller et al., 19 adult AML patients, undergoing different preparative regimens, were infused with overnight IL-2 activated haploidentical NK cells followed by daily subcutaneous injection of IL-2 for 14 days [132]. Adoptively transferred human NK cells were safe and could be expanded in vivo. Indeed, circulating haploidentical NK cells were observed up to 28 days after infusion. The expansion was observed in patients with the more intense Cy/Flu preparative regimen, which was associated with high serum concentrations of IL-15. Notably, 5 of 19 poor prognosis AML patients achieved complete remission (CR) after haploidentical NK cell therapy, with a significantly higher rate when KIR ligand mismatched donors were used. IL-15 could be a suitable alternative of IL-2 for adoptive NK cell therapy because it avoids Treg stimulation (see 4.1 paragraph). The results of the first phase I/II clinical trials with recombinant human IL-15 (rhIL-15), administered either by subcutaneous (sc) or intravenous (iv) injection, and haploidentical NK cell therapy after lymphodepletion in relapsed/refractory AML patients have been recently published [133]. Beneficial clinical responses have been observed, and rhIL-15 induced in vivo NK cell expansion and remission rates better than those observed in previous trials with IL-2. However, unexpectedly, 
after sc and not iv treatment with rhIL-15, high frequency of cytokine release syndrome (CRS) and neurotoxicity was observed. Further studies of pharmacokinetics and pharmacodynamics will be necessary to optimize the therapeutic benefits of IL-15 and minimize CRS.

Additional studies have shown the efficacy of the adoptive transfer of haploidentical KIR/KIR-L mismatched NK cells in children, adults, and high-risk elderly patients with AML, not candidates to receive HSCT. In the pilot study of haploidentical NK cell transplantation for AML (NKAML), the safety and feasibility of low-dose immunosuppression followed by the infusion of highly purified haploidentical NK cells in children with AML were assessed [134]. All patients showed safe engraftment, with an expansion of donor-derived alloreactive NK cells during the first four weeks after infusion, and remained in CR after a follow-up of approximately 32 months.

In high-risk elderly patients with AML infused with highly purified alloreactive NK cells from haploidentical donors after Cy/Flu immunosuppressive chemotherapy followed by in-vivo IL-2 administration, no NK cell-related toxicity, including GvHD, was observed [135]. The procedure was beneficial for the outcome of patients treated in CR or very early in molecular relapse, or both. Thus, the infusion of purified NK cells is feasible in elderly AML patients as a post-CR consolidation strategy. This study also documented the kinetics of emergence and persistence over time of functional donor-versus-recipient NK cell alloreactivity after NK cell infusion. In addition, the infusion of high numbers of alloreactive NK cells can improve the clinical efficacy of adoptively transferred haploidentical NK cells [136].

Therefore, the infusion of a defined number of functionally active NK cells could be of great impact on the efficacy of NK cell-based treatment. The selection of haploidentical donors predictive of patients response upon adoptive transfer of NK cells should be valorized, as well [137].

\section{Strategies to Induce NK Cell Activation, Persistence, and Expansion}

\subsection{Cytokine-Mediated NK cell Activation and Expansion to Improve Tumor Killing}

Antitumor NK cell functions can be modulated not only by the direct ligand-receptor interactions, but also by several cytokines. In particular, IL-2, IL-12, IL-15, IL-18, and IL-21 can activate NK cells, whereas suppressive cytokines, including TGF- $\beta$ or IL-10, can inhibit them $[138,139]$. To improve antitumor responses, cytokine therapies capable of supporting NK cell differentiation, activation, persistence, and expansion have been tested in preclinical studies and clinical trials [140,141] (Figure 2).

The first cytokine shown to exert a relevant role in the treatment of tumors was IL-2 [142]. IL-2 can mediate its effects by binding to a high-affinity receptor composed of IL-2R $\alpha, I L-2 R \beta$, and the common $\gamma$ chain. In NK cells the engagement of the IL-2R complex by IL-2 leads to phosphorylation of STAT-1, -3 , and -5; activation of p38 MAPK [143]; and later, induction of NK cell proliferation and increment of NK cell cytotoxicity [144]. However, the administration of high doses of IL-2 is associated with an increased risk of severe adverse reactions, including vascular leakage and organ injury caused by activation of the vascular endothelium (which is characterized by the expression of the IL-2 high affinity receptor, IL-2R $\alpha \beta \gamma$ ), and also with poor therapeutic index [145-150]. Indeed, IL-2 can also bind to the IL-2R $\alpha \beta \gamma$ on Treg cells and, as a consequence, it can indirectly inhibit NK cell proliferation and cytotoxicity through the action of TGF $\beta$ released by IL-2 activated Treg cells [151], and through the deprivation of IL-2 by Treg cells [152,153]. On the other hand, it is important to remember that the use of low doses of IL-2 to expand NK cells after autologous transplantation was shown to result in efficient in vivo expansion of NK cells [154], but with limited antitumor efficacy, probably due to inhibitory signals occurring upon KIR/NKG2A-mediated self-HLA class I engagement and the stimulation of suppressive Treg cells by IL-2 $[155,156]$. Thus, high doses of IL-2 were necessary for an efficient antitumor activity, but were also responsible for inducing severe toxicity. For these reasons, strategies useful for the production of modified forms of IL-2, capable of immunoactivation and avoiding immunosuppression, became necessary. Along this line, mutant forms of IL-2 with high 
affinity for IL-2R $\beta \gamma$ present on NK cells, but reduced affinity for IL-2R $\alpha$ expressed on Treg cells, have been generated [157-159] (Figure 2).

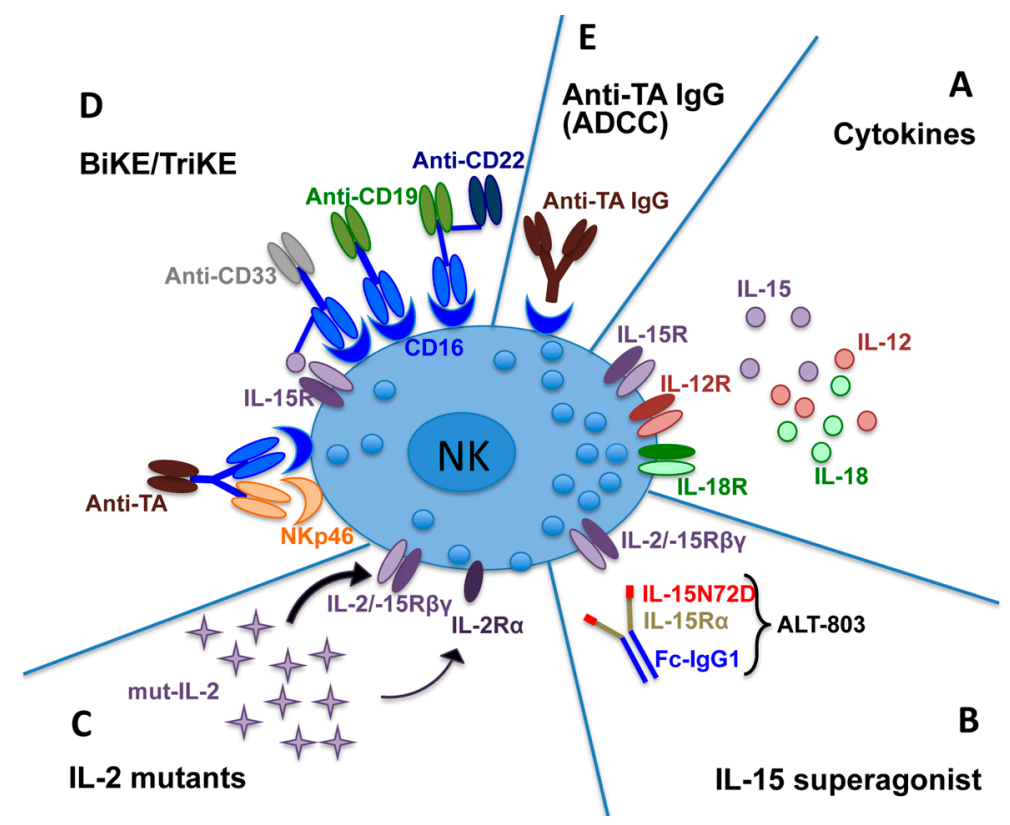

Figure 2. Different strategies can be used to induce activation and expansion of natural killer (NK) cells to improve tumor killing. (A) Cytokines, such as interleukin (IL)-15, IL-12, and IL-18 to generate cytokine induced memory-like NK cells (CIML-NK); (B) IL-15 superagonist ALT-803, an IL-15 mutant (IL-15N72D) bound to a soluble, dimeric IL-15R $\alpha$ Fc fusion protein (IL-15R $\alpha$-FC); (C) IL-2 mutants with high affinity for IL-2R $\beta \gamma$ present on NK cells, but reduced affinity for IL-2R $\alpha$ expressed on Treg cells; (D) activating NK cell receptor engagement by the use of bispecific or trispecific killer engagers (BiKE or TriKE), capable of binding CD16 on NK cells and one/two tumor antigen(s) (e.g., CD19, CD22, CD33) or CD16 and NKp46 on NK cells and one tumor antigen; (E) tumor-specific antibodies (IgG), capable of inducing the NK-antibody dependent cell-mediated cytotoxicity(ADCC). TA, tumor antigen.

Another cytokine capable of activating NK cells is represented by IL-15, a soluble factor that shares many activities with IL-2 (probably because these cytokines use common receptor subunits), but that, differently from IL-2, does not induce Treg-mediated immune suppression [160]. IL-15 interacts with a heterotrimeric receptor composed by the $\beta$ and common $\gamma$ chain of the IL-2R [161] and the unique high affinity IL-15-binding subunit, called IL-15R $\alpha$ [162,163]. Notably, cells expressing IL-2R $\beta \gamma$, but not IL-15R $\alpha$, can bind and respond to IL-15 only when high concentrations of this cytokine are present. On the contrary, IL-15R $\alpha$ binds to IL-15 with high affinity, also in the absence of the IL-2R $\beta \gamma$. Moreover, on the surface of dendritic cells or other myeloid cells, IL-15R $\alpha$ can present IL-15 in trans to IL-2R $\beta \gamma$ receptors expressed on NK and CD8 ${ }^{+} \mathrm{T}$ cells, without activating Tregs [164]. However, the clinical use of IL-15 is impaired by its short half-life. Strategies to improve IL-15 administration and dosing are still being studied to optimize its biological effects, reducing toxicity [133]. Rubinstein and colleagues demonstrated that the combination of IL-15 with the IL-15R $\alpha$ subunit formed a soluble compound (termed IL-15 superagonist) with significantly longer half-life and higher biological activity than native IL-15 [165].

In order to further increase the in vivo half-life of IL-15, the IL-15 superagonist ALT-803 has been recently developed by binding an IL-15 mutant (IL-15N72D) to a soluble, dimeric IL-15R $\alpha$ FC fusion protein (IL-15R $\alpha-\mathrm{Fc}$ ) (Figure 2). This compound has a prolonged half-life and an increased ability to bind IL-2R $\beta \gamma$ and mediate immunostimulatory functions as compared to IL-15 alone [166,167]. Preclinical studies have shown that ALT-803 can mobilize both innate and adaptive immune responses by enhancing NK and T cell functions. Recently, in a phase I study, clinical benefits upon iv or 
sc ALT-803 administration have been observed in patients with hematologic malignancies who had relapsed after allogeneic HSCT [168]. In these patients, ALT-803 was generally well-tolerated, with no severe toxicities and GvHD. Moreover, ALT- 803 has been used as a functional scaffold for creating multispecific, targeted IL-15-based immunotherapeutic agents to enhance tumor clearance. Indeed, ALT- 803 has been fused to four single chains of Rituximab to generate the 2B8T2M molecule, a compound displaying trispecific activity: recognition of CD20 on tumor cells, stimulation of IL-2R $\beta \gamma$ on immune cells, and binding of Fc $\gamma \mathrm{R}$ on NK cells and macrophages [169]. Thus, NK cells can be activated inducing the killing of B-lymphoma cells through ADCC.

A recent study has demonstrated that the IL-15-AKT-XBP1s signaling pathway contributes to enhance antitumor effector functions and NK cell survival. In particular, the protein stability of XBP1s, induced by the IL-15-mediated phosphorylation of AKT, positively regulates the expression of granzyme B and the antileukemia activity of NK cells [170].

The short ex vivo treatment of NK cells with a combination of IL-15, IL-12, and IL-18 before NK cell adoptive transfer is another promising cytokine-based approach for antitumor clinical applications (Figure 2). Indeed, these cytokine-primed NK cells, called "cytokine induced memory-like NK cells" (CIML-NK), have been shown to be long-lived and memory-like NK cells, characterized by enhanced IFN- $\gamma$ production and cytotoxicity against tumor cells [171-174]. Preactivation of NK cells with IL-18/IL-15/IL-12 was also shown to increase the expression of CD25 and, as a consequence, favor the survival of NK cells in patients, even without administration of exogenous IL-2 and any toxicity. On the other hand, IL-18/IL-15/IL-12 treatment could also induce negative effects on NK cells, for example the reduction of CD16 expression that, however, could be restored by removing cytokine stimulation. Notably, this type of NK cell expansion allowed large-scale NK cell production, useful for repeated therapeutic use, and the adoptive transfer of these cytokine-primed NK cells was effective, as demonstrated in murine cancer models and in clinical trials [171,172]. CIML-NK cells display enhanced IFN- $\gamma$ production and cytotoxicity against leukemia cell lines or primary human AML blasts in vitro, regardless of KIR/KIR-L interactions. Moreover, a first-in-human phase I clinical trial demonstrated CIML-NK cell expansion and robust responses against AML blasts [175].

Another cytokine, which is known to be involved in development/proliferation of NK cells from progenitor cells, induction of NK cell receptor expression, IFN- $\gamma$ secretion, and cytotoxicity, is IL-21. However, it is important to underline that the role of this cytokine on NK cell function is controversial; indeed, it has also been reported to trigger apoptosis and diminish the positive effects of IL-15 [176]. According to the high potential of IL-15 in NK cell expansion and the effects of IL-21 on NK cell maturation and function $[177,178]$, a two-phase expansion protocol based on the use of IL-15 to induce an early NK cell expansion, followed by short exposure to IL-21 to boost NK cell cytotoxicity against tumor cells, has been developed [179].

Moreover, a method to expand NK cells ex-vivo using genetically modified K562 feeder cells equipped with membrane-bound IL-21 (K562mb-IL-21) has been developed [180]. Recently, this method, used in a phase I clinical trial for the ex vivo expansion of donor-derived NK cells in haplo-HSCT, has been demonstrated to be safe and effective in controlling leukemia with no major toxicity and to be associated with significantly improved NK cell number and function, lower viral infections, and low post-transplant relapse rate [117].

\subsection{CD16-Mediated Tumor Cell Killing to Cure Hematological Malignancies}

Besides the use of cytokines to drive NK cell activation and function against malignancies, other immunotherapeutic strategies enhancing NK cell antitumor potential are based on the innate ability of NK cells to kill target cells opsonized with antibodies via ADCC. This mechanism implies the engagement of the activating receptor $\mathrm{CD} 16$ (Fc $\gamma$ RIIIa), which recognizes and binds the immunoglobulin Fc fragment with low affinity [30]. The first therapeutic interventions taking advantage of CD16 function on NK cells were based on the administration of tumor-targeting chimeric monoclonal antibodies (mAbs), such as rituximab, a mAb recognizing CD20 that still represents a first-line treatment in 
B-chronic lymphocytic leukemia (B-CLL) [181] (Figure 2). To increase mAbs' affinity for CD16, humanized mAbs, such as obinutuzimab (anti-CD20), have also been generated by engineering the Fc fragment [182], possibly translating their higher affinity to a better clinical outcome [183]. Interestingly, these modifications were capable of augmenting CD16 affinity for IgG also in individuals carrying the polymorphism that decreases CD16 Fc-binding capacity (i.e., bearing a CD16A-158F allotype instead of the high affinity CD16A-158V allotype) [184-186]. Indeed, the low-affinity CD16 form has been associated with inferior therapeutic effects of rituximab in lymphoma patients $[187,188]$. Along this line, a Fc-modified anti-CD133 with higher affinity for Fc was shown to elicit improved NK cell responses in a xenograft model of human AML [189].

In view of the high clinical potential of CD16-mediated tumor cell killing to cure malignancies, different approaches have been recently developed to further improve NK cell activation through this receptor. Following the strategy applied to generate T cell engaging antibodies (BiTE), such as blinatumomab, a CD19/CD3-bispecific single chain T-cell engager employed for relapsed/refractory ALL $[190,191]$, bispecific antibodies and BiKEs-triggering NK cells have been produced. While BiTEs can show adverse side effects [192,193], BiKEs promise to be safer, more efficacious, and flexible. These molecules couple immune cell engagement to tumor targeting by forming an immunological synapse between NK and tumor cells. Indeed, BiKEs are composed of a single-chain variable fragment $(\mathrm{scFv})$ of an antibody specific for a given tumor antigen, connected through a short peptide linker to an anti-CD16 scFv, which triggers stronger cytotoxic signals in NK cells as compared to those elicited by Fc fragments binding to CD16 [194]. BiKEs engaging CD16 and recognizing CD19 [195] (Figure 2) or CD33 [196] have been developed and tested also in combination with an inhibitor of the metalloprotease ADAM17 [197] to avoid/limit CD16 shedding from NK cell surface. These novel immune engagers offer high flexibility and can be tailored to better fit clinical needs, such as improvement of NK cell survival and proliferation. To this end, a TriKE incorporating IL-15 has been designed. In particular, the $16 \times 15 \times 33$ TriKE (Figure 2) has shown enhanced NK-mediated killing of AML and MDS in both in vitro and in vivo preclinical models $[198,199]$. Similarly, a novel CD19-targeting $16 \times 15 \times$ 19 TriKE holds great potential to cure refractory B-CLL [200]. In addition, BiKEs and TriKEs can be also engineered to contain two different tumor specificities permitting them to circumvent the complication represented by the emergence of tumor cells lacking the selected tumor antigen. In this context, a TriKE containing anti-CD19 and anti-CD22 has been designed [195] to overcome the possible appearance of $\mathrm{CD} 19^{-}$leukemic blasts that was observed upon blinatumomab treatment in around $20 \%$ of pediatric B-ALL patients given the drug [201] (Figure 2). Alternatively, more selective tumor antigens have been introduced in TriKE platforms such as C-type lectin domain family 12 member A (CLEC12A), which is highly expressed also on CD33- AML cells and could better contribute to myeloid leukemia targeting by NK cells [202].

Further improvements will be achieved by the use of novel platforms that are under development by different groups and companies. For example, ROCK $^{\circledR}$ (redirected optimized cell killing) is a registered trademark multispecific platform that permits researchers to create tetravalent NK cell engagers composed of a specific CD16A antibody linked to a bispecific anti-tumor antigen [203]. These molecules promise to be efficacious independently of CD16A allotype, to prevent NK cell fratricide, and to avoid inhibition by serum IgG. Indeed, a tetravalent anti-CD30/CD16A tandem diabody (AFM13) has been successfully tested in a phase I trial and a phase II study is planned for relapsed/refractory Hodgkin's lymphoma patients [204].

Remarkably, the use of immune engagers retargeting and potentiating ADCC could be particularly efficient in patients characterized by the presence of HCMV-driven adaptive NK cells. This peculiar NK cell subset is present at variable proportions in $\mathrm{HCMV}^{+}$healthy donors $[205,206]$ and can develop in noticeable amounts in leukemic patients undergoing HCMV reactivation after HSCT [192,207-209]. Adaptive $\mathrm{NK}$ cells are usually characterized by a $\mathrm{NKG}_{2} \mathrm{C}^{+} \mathrm{CD} 57^{+}$surface signature, epigenetic modifications, and altered signaling molecules expression that enhance their ADCC potential, suggesting that these cells could provide optimal responses to CD16-engaging molecules [210,211]. 
Besides enhanced ADCC, adaptive NK cells show strong cytotoxicity in response to NKG2C triggering. Along this line, a novel TriKE composed of an anti-NKG2C combined with an anti-CD33 and IL-15 has been successfully used in vitro to augment AML killing by iPSC-derived NK cells (see 5. paragraph) engineered to express NKG2C [212].

Notably, CMV-induced adaptive NK cells could play an inherent role in preventing leukemia relapse and promoting better clinical outcomes, as recently suggested in the HSCT setting $[108,208,209]$. Interestingly, a protocol aimed at expanding $\mathrm{CMV}$-induced $\mathrm{NKG}_{2} \mathrm{C}^{+} \mathrm{NK}$ cells for cell therapy has been recently developed to treat pediatric T- and precursor B-ALL [213]. The optimization of expansion protocols combined with the use of appropriate immune engagers will fully exploit the antileukemic properties of adaptive $\mathrm{NKG}_{2} \mathrm{C}^{+} \mathrm{NK}$ cells.

Along with CD16 triggering, the engagement of NCRs could be relevant to achieve optimal NK cell activation against acute leukemia and other hematological malignancies. In a very recent study, trifunctional natural killer cell engagers (NKCEs) targeting CD16 and NKp46 combined with an antitumor antigen (e.g., CD20) (Figure 2) have been proven to induce full activation and enhanced target cell killing, as compared to standard mAbs (e.g., rituximab), in both in vitro and mouse models [214].

NK cell-based immune engagers represent a very plastic tool that can be managed and adapted to different patient needs more easily than other approaches (e.g., adoptive cell transfer, engineering). Although clinical trials based on NK cell immune engagers are at the beginning and novel molecules are in early developmental stages, NK cell engagers hold great potential to transform future antileukemic therapies, especially in combination with both conventional chemotherapy or allo-HSCT and other innovative immunotherapeutic strategies, such as cytokine-based stimulation and immune checkpoint inhibitors.

\subsection{Restoration of NK-Mediated Antitumor Responses by the Use of Antibodies Blocking Immune Checkpoints}

A promising therapeutic approach to cure leukemia patients is represented by the use of monoclonal antibodies capable of both disrupting the interactions between the immune checkpoints (expressed on NK cells) and their ligands (expressed on tumor cells), and restoring efficient NK-mediated antitumor responses. For example, the fully human IgG4 mAb lirilumab, directed against a common epitope shared by KIR2D, has been shown to block the KIR/KIR-L interaction and increase NK cell-mediated killing of AML blasts both in vitro and in vivo [215]. Lirilumab showed acceptable safety without significant toxicity in AML and CLL patients [216]. Moreover, although a single-agent phase I trial with lirilumab has not shown significant efficacy in relapsed/refractory MM [217], the lirilumab/lenalidomide combined therapy has displayed a good response in a following phase I clinical trial in patients affected by the same malignancy [218], confirming that combined blockade of different immune checkpoints is a promising therapeutic strategy. Along this line, analyses evaluating the efficacy of lirilumab in combination with other therapeutics are ongoing. For example, there are: (1) a phase II study evaluating the combination of lirilumab with rituximab (anti-CD20 mAb) for relapsed, refractory, or high-risk untreated patients with CLL (NCT02481297); (2) a phase II study evaluating lirilumab in combination with 5-azacytidine for the treatment of patients with refractory/relapsed AML (NCT02399917); (3) a phase II study analyzing the combined use of lirilumab and nivolumab with 5-azacitidine in patients with myelodysplastic syndromes (MDS) (NCT02599649).

Another mAb used in immunotherapy to potentiate NK cell function is represented by the humanized anti-NKG2A monalizumab (IPH2201), which is capable of blocking the NKG2A/HLA-E interaction [219]. Various clinical trials are evaluating the efficacy of monalizumab in different types of tumors. Regarding the treatment of hematological malignancies, a phase I clinical trial based on the use of monalizumab as monotherapy is ongoing to determine the safety of monalizumab after HLA-matched allogenic HSCT (NCT02921685). Moreover, a phase I/II clinical trial evaluating the combined use of monalizumab with the Bruton's tyrosine kinase inhibitor ibrutinib in patients with relapsed, refractory, or previously untreated CLL is ongoing (NCT02557516). 


\section{Adoptive Cell Therapy Using Chimeric Antigen Receptor-Engineered Natural Killer Cells}

In lymphoid B-cell neoplasia, adoptive cell therapy based on the use of $\mathrm{T}$ cells engineered with a chimeric antigen receptor (CAR)-T has achieved exciting results [220-222]. Two anti-CD19 CAR-T therapies have been approved by the Food and Drug Administration (FDA) first, and then by the European Medicine Agency, for treatment of relapsed B-cell ALL and refractory/relapsed large B-cell non-Hodgkin's lymphoma (NHL). However, the application of CAR-T cells is hampered by several obstacles, limiting a widespread clinical use; they include: (i) high cost associated with the drug product, since it requires a single manufacturing for each patient; (ii) significant delay between patient enrollment and treatment, this being associated with the need to define salvage therapy between apheresis and CAR-T cell infusion; (iii) the lack of possibility to reinfusing the drug product in patients experiencing low CAR-T cell persistence or disease relapse; (iv) the majority of patients experience high rate of toxicity, due to the production of IFN- $\gamma$ and the consequent induction of the CRS and/or neurotoxicity; (v) difficulties in the management of the industrial chain for the autologous drug product's worldwide distribution.

In this scenario, the development of an allogeneic platform based on NK cells could represent an appealing solution for almost all the above-mentioned hurdles. Indeed, CAR-NK cells do not require HLA matching to be cytotoxic and can be used in allogeneic settings without causing GvHD, thus representing a valid system for the generation of "off-the-shelf" products for clinical use [79,102,223,224]. NK cells express activating receptors, such as NCRs, NKG2D, and DNAM-1, that may be engaged synergistically and independently from CAR, triggering NK killing capability and potentially bypassing loss of targeted antigens as a tumor escape mechanism. Moreover, the ADCC ability of NK cells mediated by CD16 expression is an additional tumor-killing strategy $[45,225]$ that could be used in synergy with the CAR antitumor activity (Figure 3). Nowadays, several different sources of NK cells have been considered for the generation of CAR-NK cells, at both preclinical and clinical levels, including NK cell lines (NK-92 [226], KHYG-1 [227], NKL, NKG, YT, etc.), and NK cells from UCB, PB, and, more recently, induced pluripotent stem cells (iPSCs) [228,229] (Figure 3).

The human NK cell line, NK-92 [226], derived from PB of a patient with aggressive non-Hodgkin's lymphoma carrying several cytogenetic alterations and the integration of EBV DNA, was chosen from different groups as the NK platform since it can be easily expanded under good manufacturing practice (GMP) standards for clinical applications [230] and provides a homogenous NK cell population. Indeed, the unmodified NK-92 line has been approved by the US FDA for use in clinical trials, after its irradiation and before adoptive transfer, to prevent propagation in patients [231], proving its safety in a phase I/II trial [231-233]. To date, CAR-NK-92 cells have been extensively investigated preclinically in several models, including arming the cell line with CARs that recognize HER2 [234], CD19 [233,235], CD20 [236], CD38 [237], CD7 [238], CD3 [239], CD5 [240], GD2 [241], EBNA [242], EGFR and EGFRvIII [243], EpCAM [244], mesothelin [228], and CS1 [245]. The clinical application of CAR-NK-92 cells has been restricted. In particular, data are available of only one first-in-men trial based on CAR.CD33 NK-92 cell infusion in three patients with relapsed and refractory AML [246]. This study showed that at doses up to $5 \times 10^{9}$ irradiated cells per patient, no significant adverse effects were observed, along with marginal and transient patient response. To date, the attempt to optimize CAR-NK-92 approaches is currently under evaluation in several clinical trials that include CAR-modified NK-92 for HER-2 targeting in glioblastoma (NCT03383978), BCMA targeting in multiple myeloma (NCT03940833), and CD19 targeting in CD19+ leukemia and lymphoma (NCT02892695). 


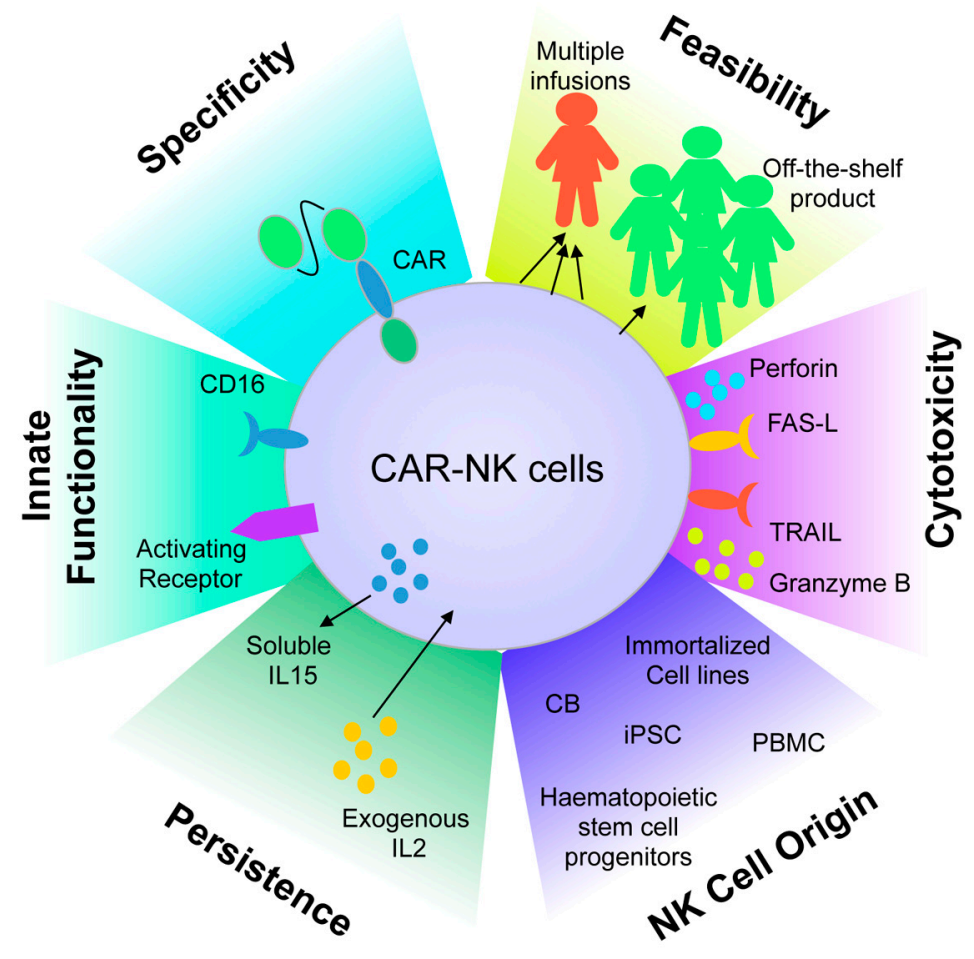

Figure 3. Benefits of chimeric antigen receptor-natural killer (CAR-NK) cells. NK cells of different origin can be genetically modified through the use of CAR constructs able to redirect their specificity against antigens expressed on tumor cells. These NK cells can be further expanded ex vivo to reach clinically meaningful numbers, and further optimized by the activation of their native receptors, including CD16 for the antibody dependent cell-mediated cytotoxicity (ADCC) mechanism. CB, cord blood; iPSC, induced pluripotent stem cells; PBMC, peripheral blood mononuclear cells; FAS-L, FAS-ligand; IL2, interleukin-2; IL15, interleukin-15; TRAIL, tumor necrosis factor (TNF)-related apoptosis-inducing ligand.

An important question is whether gene-modified NK cell lines represent better CAR effector cells than primary human donor CAR-NK (CAR-dNK) cells, in terms of reproducibility, viability, effectiveness, risk of side effects, and clinical practicality/applicability. Although the formal comparison of the functional activities of sorted CAR-NK cells generated using the NK-92 cell line with those generated from CAR-dNK cells was recently conducted in an vitro model, demonstrating that CAR-NK-92 cells had stronger cytotoxic in vitro activity against leukemia cells compared to CAR-dNK cells [247], various evidence suggests that NK-92 cells could not be the best NK recipient for CAR-engineering. Indeed, irradiated NK-92 cells have no possibility to expand in vivo after the infusion, the lack of CD16 strongly impairs ADCC, and the lack of NKp44 expression [248,249] compromises the natural cytotoxicity in comparison to activated primary NK cells.

UCB-derived primary NK cells have been explored as a possible platform for CAR approaches for several reasons, including low risk of viral transmission from donor to recipient, rapid availability of UCB units serving as an immediate "off-the-shelf" product, less stringent requirements for HLA matching, and lower risk of GvHD [250]. In vitro models have been developed to optimize the GMP expansion of large-scale UCB-NK cells, using artificial antigen-presenting cells (aAPCs) expressing several costimulatory molecules in association to either membrane-bound IL-21 [180,251] or membrane-bound IL-15 [252]. This last approach has been considered to generate CAR.CD19 NK cells that also produce soluble IL-15 to boost in vivo expansion and persistence, as already demonstrated in a preclinical model [253], and is now under clinical evaluation at M.D. Anderson Cancer Center (recruiting trial NCT03056339 and not yet recruiting trial NCT03579927). Early data on the clinical efficacy of CAR-NK therapy suggest that UCB-derived NK cells transduced with CD19 CARs can 
be used safely and effectively as off-the-shelf products in patients with B-cell malignancies (oral communication at IACH 2018 meeting. link: http://cme-utilities.com/mailshotcme/IACH/Summaries/ Rezvani\%20Innate\%20Killer\%20meeting_2018.pdf). Beside the great advantages in the use of UCB as a source for NK cells, the major limitation is represented by the fact that UCB contains between 10and 100-fold fewer nucleated cells than other sources of NK cells [250], limiting the amount of cells of interest that can be retrieved from one UCB unit for the generation of off-the-shelf CAR-NK cell banks. This is the reason why we, and other groups, are currently investigating the feasibility and efficacy of CAR-NK cells derived from PB of healthy donors. Several attempts have been conducted in order to obtain large numbers of NK cells from PB sources [132,254-259], whereas few of them were associated with the generation of CAR-NK cells. In particular, the feeder expanded approach based on the K562 cell line modified to express membrane-bound IL-15 and 41BB ligand [260] was considered for the manufacturing of PB-derived CAR-NK cells in at least two pilot clinical trials (NCT01974479 in Singapore and NCT00995137 in Memphis USA). Recently, an innovative strategy to generate CAR-NK cells without the use of a feeder layer has been described. In particular, this last approach has been tested in the model of CAR.CD19 NK cells by our group and represents a great advantage in terms of GMP manufacturing as well as safety requirements [261]. The feeder-free, bovine serum-free protocol is based on the ex vivo stimulation of NK cells by monoclonal Ab directed against NCRs to generate high-purity, functional, and expandable PB-NK and PB-CAR-NK cells from widely available donor-derived leukapheresis products or PBMCs. The CAR-NK cells express a broad number of relevant NK cell markers and receptors, indicating that the established method is able to genetically modify and expand heterogeneous NK cells, regardless of their maturation stage and cytokine-induced activation [261].

Stem cells (i.e., CD34 $4^{+}$hematopoietic progenitors from peripheral blood and UCB, as well as iPSC) offer another renewable source of CAR-NK cells that can be standardized as an off-the-shelf therapy. While the generation of NK cells from CD34 ${ }^{+}$, human embryonic stem cells (hESCs), or iPSC has been largely investigated by different approaches, the ex vivo expansion of CAR-NK cells from these sources has been limited to few reports. In particular, CAR-NK cells have been generated from HSC derived from UCB by using an optimized protocol based on the ex vivo expansion of nonirradiated murine OP9-DL1 stroma in the presence of IL-7 and IL-15 [262]. This approach was feasible, although no scalability proof has been conducted so far to prove its applicability in the generation of CAR-NK off-the-shelf cellular banks. This latter approach, indeed, was carried out by groups working on CAR-NK derived from iPSC [228,229]. The use of iPSC-derived NK cells is currently under early clinical evaluation for safety and feasibility (NCT03841110), paving the way to the iPSC-CAR-NK approach in the near feature.

Of notice, it is also relevant to consider that up to now, most CARs were not optimized for NK cells, saving the $\mathrm{CD} 3 \zeta$ domain. One attempt to completely substitute this region, if of any advantage, is represented by the construction of a chimeric molecule between the extracellular region of the inhibitory receptor PD-1 and the transmembrane domain of the activating receptor NKG2D to reverse the immune escape mediated by PD-1 ligands in solid tumors [263]. The authors identified a chimeric PD1-NKG2D receptor containing a NKG2D hinge region and 4-1BB costimulatory domain to obtain stable surface expression and to mediate in vitro cytotoxicity of NK92 cells against various tumor cells [263]. A second approach was to exploit DAP12, a signaling adaptor molecule involved in signal transduction of activating NK cell receptors, fused to the anti-prostate stem cell Ag (PSCA) scFv(AM1) to confer improved cytotoxicity to the NK cell line, YTS, against PSCA-positive tumor cells [264], or fused to the extracellular domain of NKG2D itself [265]. This approach is of particular interest, since it was tested in a pilot clinical trial in three patients with chemotherapy-refractory metastatic colorectal cancer to evaluate the safety and feasibility of adoptive cell therapy with primary feeder-expanded NK cells modified by mRNA electroporation. Patients received multiple infusions of autologous engineered CAR-NK cells (first patient) or allogeneic CAR-NK cells from HLA-haploidentical family donors (second and third patients) with no dose-limiting toxicities or serious adverse effects. Importantly, only 
grade 1 CRS was reported, associated with fever, fatigue, and anorexia, whereas GvHD was not observed in the two patients treated with haploidentical NK cells [265].

Independently from the applied source for CAR-NK cells and the CAR design itself, the level of CAR expression has been one of the major issues associated with the clinical translation of the approach. Retroviral and lentiviral transductions are the two major platforms used for the stable expression of CAR in NK cells, whereas RNA electroporation approach, providing transient CAR expression, was adopted as a risk mitigation strategy by several groups [266,267]. Moreover, the comparison between lentiviral and mRNA electroporation of CAR in NK cells has been formally conducted, with the great advantage of mRNA electroporation only in the NK-92 cell line, whereas primary NK cells could be efficiently transduced only upon high title lentiviral exposure [268].

Besides all the preclinical achievements in the field of CAR-NK cells, further research, as well as pilot clinical trials (Table 1), are needed to investigate efficacy and feasibility of this novel and intriguing approach, in an attempt to build a novel concept of tailored therapy, in which allogenic effector cells could be used to maximize CAR cell therapy.

Table 1. Active clinical CAR NK cell trials with a known status (source: ClinicalTrails.gov).

\begin{tabular}{|c|c|c|c|c|c|c|c|}
\hline Identifier & $\begin{array}{c}\text { NK } \\
\text { Type/Source }\end{array}$ & CAR Target & Conditions & Phase & Status & $\begin{array}{c}\text { Last } \\
\text { Up-Date }\end{array}$ & Location \\
\hline NCT03415100 & $\begin{array}{l}\text { Autologous or } \\
\text { allogeneic } \\
\text { NK cells }\end{array}$ & NKG2D-Ligand & $\begin{array}{l}\text { Metastatic Solid } \\
\text { Tumours }\end{array}$ & I & Recruiting & August, 2018 & China \\
\hline $\begin{array}{l}\text { NCT03056339 } \\
\text { NCT03579927 }\end{array}$ & $\begin{array}{l}\text { Primary } \\
\mathrm{NK} / \mathrm{CB}\end{array}$ & CD19-IL15 & $\begin{array}{l}\text { B Lymphoid } \\
\text { Malignancies }\end{array}$ & $\begin{array}{l}\mathrm{I} / \mathrm{II} \\
\mathrm{I} / \mathrm{II}\end{array}$ & $\begin{array}{l}\text { Recruiting } \\
\text { Not yet } \\
\text { recruiting }\end{array}$ & $\begin{array}{l}\text { July, } \\
\text { 2019/October, } \\
2019\end{array}$ & USA \\
\hline NCT03692767 & ND & $\mathrm{CD} 22$ & $\begin{array}{c}\text { Relapsed } \\
\text { Refractory } \\
\text { B cell Lymphoma }\end{array}$ & I & $\begin{array}{l}\text { Not yet } \\
\text { recruiting }\end{array}$ & January, 2019 & ND \\
\hline NCT03690310 & ND & CD19 & $\begin{array}{c}\text { Refractory } \\
\text { B Cell Lymphoma }\end{array}$ & I & $\begin{array}{l}\text { Not yet } \\
\text { recruiting }\end{array}$ & January, 2019 & ND \\
\hline NCT03692663 & ND & PSMA & $\begin{array}{l}\text { Castration-Resistant } \\
\text { Prostate Cancer }\end{array}$ & I & $\begin{array}{l}\text { Not yet } \\
\text { recruiting }\end{array}$ & October, 2018 & ND \\
\hline NCT03824964 & ND & CD19/CD22 & $\begin{array}{c}\text { Relapsed and } \\
\text { Refractory } \\
\text { B Cell Lymphoma }\end{array}$ & I & $\begin{array}{l}\text { Not yet } \\
\text { recruiting }\end{array}$ & January, 2019 & ND \\
\hline NCT03692637 & ND & Mesothelin & $\begin{array}{l}\text { Epithelial Ovarian } \\
\text { Cancer }\end{array}$ & I & $\begin{array}{l}\text { Not yet } \\
\text { recruiting }\end{array}$ & January, 2019 & ND \\
\hline NCT03940833 & NK-92 & BCMA & $\begin{array}{c}\text { Relapsed/Refractory } \\
\text { MM }\end{array}$ & I & Recruiting & May, 2019 & China \\
\hline $\begin{array}{l}\text { NCT03940820 } \\
\text { NCT03931720 }\end{array}$ & ND & ROBO1 & $\begin{array}{c}\text { Metastatic Solid } \\
\text { Tumours/Malignant } \\
\text { Tumors }\end{array}$ & $\begin{array}{c}\text { I } \\
\text { I/II }\end{array}$ & Recruiting & May, 2019 & China \\
\hline NCT03941457 & ND & ROBO1 & Pancreatic Cancer & $\mathrm{I} / \mathrm{II}$ & Recruiting & May, 2019 & China \\
\hline NCT03383978 & NK-92 & HER-2 & Glioblastoma & I & Recruiting & May, 2019 & Germany \\
\hline
\end{tabular}

\section{Concluding Remarks}

The improved knowledge on the NK cell biology has led to increased interest in the development of different immunotherapeutic approaches based on the use of these cells, and numerous studies have been conducted to exploit their powerful antitumor activity. In particular, the potent cytotoxicity of NK cells has been employed to treat hematological malignancies using two different approaches: (1) adoptive transfer of mature NK cells; and (2) haplo-HSCT, where mature donor NK cells are generated in vivo from HSCs and/or transferred with the graft (Figure 4). 


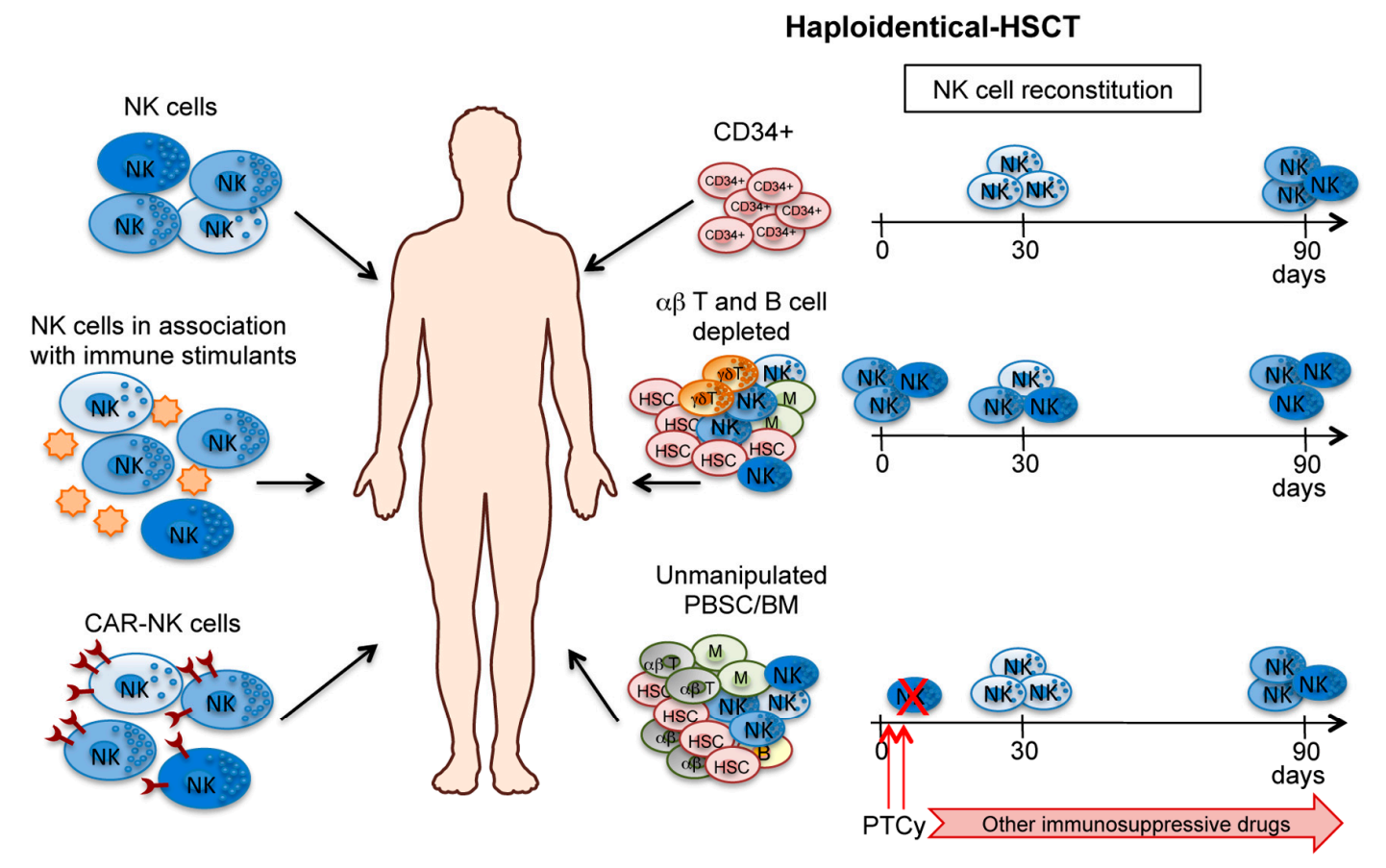

Y CAR

Cytokines, BiKE, TriKE, etc

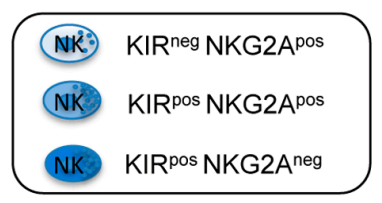

Figure 4. Different therapeutic approaches based on the use of natural killer (NK) cells. Adoptive transfer: infusion of unmodified allogeneic NK cells (directly or in combination with different types of immune stimulants) or chimeric antigen receptor (CAR)-modified allogeneic NK cells. Different strategies of haploidentical-HSCT: graft inoculum of "megadoses" of highly purified CD34 ${ }^{+}$ cells; infusion of a $\alpha \beta \mathrm{T}$ - and CD19 B cell-depleted graft enriched for hematopoietic stem cells (HSC) and also containing other cell types, including mature (possibly alloreactive) NK cells and $\gamma \delta \mathrm{T}$ lymphocytes; infusion of unmanipulated peripheral blood stem cells (PBSC)/bone marrow (BM) and early ( $+3+5$ day) post-transplant high-dose cyclophosphamide (PTCy) administration that eliminates donor-derived proliferating cells, including all mature NK cells. Graft versus host disease (GvHD) prophylaxis is given only in the third type of transplant. NK cell reconstitution in the three haploidentical-hematopoietic stem cell transplantation (haplo-HSCT) platforms is depicted, differentiating different stages of maturation. Only in $\alpha \beta$ T and CD19 B cell-depleted graft are mature NK cells infused and persist in the recipient. BiKE, bispecific killer engagers; TriKE, trispecific killer engagers.

Moreover, the in vitro or in vivo activation of NK cells with immune stimulants (including cytokines, BiKE, and TriKE) or the genetic modification of NK cells with CAR constructs specific for tumor antigens are promising strategies for potentiating and redirecting NK cell response against tumor cells. A combined use of some of these approaches may represent a novel strategy for cancer immunotherapy against hematological malignancies (Figure 4).

New perspectives can be represented by nanosized extracellular vesicles (EVs) that can be naturally secreted by several cell types including NK cells. The NK EVs contain lytic proteins, showing cytotoxic effects on different malignant cell lines, including ALL. They can also transfer bioactive molecules, easily passing through biological barriers. Thus, NK EVs have been recently proposed as a new cell-free immunotherapeutic tool $[141,269]$.

Author Contributions: S.S., R.M., C.Q., S.C., M.D.C., M.F., and D.P. wrote, referenced the review, and prepared the figures. F.L. and L.M. critically revised the manuscript. 
Funding: This research was funded by Fondazione AIRC, IG 2015 id. 16764 (D.P.), IG 2017 id. 19920 (L.M.), IG 2017 id. 20312 (S.S.), IG 2018 id. 21724 (F.L.), Fondazione AIRC 5X1000, 2018 Project Code 21147 (L.M., F.L. and S.S.), and Accelerator Award 2017 INCAR (F.L.); Ministero della Salute, GR-2013-02359212 (C.Q.), and RF-2016-02364388 (F.L.); Ministero dell'Istruzione, dell'Università e della Ricerca, PRIN 2017WC8499_004 (F.L., S.S.); Marie Curie-Sklodowska, H2020-MSCA-ITN-2017-765104 “MATURE-NK” (D.P.).

Conflicts of Interest: All authors declare no conflicting financial interests.

\section{References}

1. Vivier, E.; Raulet, D.H.; Moretta, A.; Caligiuri, M.A.; Zitvogel, L.; Lanier, L.L.; Yokoyama, W.M.; Ugolini, S. Innate or adaptive immunity? The example of natural killer cells. Science 2011, 331, 44-49. [CrossRef] [PubMed]

2. Vivier, E.; Artis, D.; Colonna, M.; Diefenbach, A.; Di Santo, J.P.; Eberl, G.; Koyasu, S.; Locksley, R.M.; McKenzie, A.N.J.; Mebius, R.E.; et al. Innate Lymphoid Cells: 10 Years On. Cell 2018, 174, 1054-1066. [CrossRef]

3. Mariotti, F.R.; Quatrini, L.; Munari, E.; Vacca, P.; Moretta, L. Innate Lymphoid Cells: Expression of PD-1 and Other Checkpoints in Normal and Pathological Conditions. Front. Immunol. 2019, 10, 910. [CrossRef]

4. Riggan, L.; Freud, A.G.; O'Sullivan, T.E. True Detective: Unraveling Group 1 Innate Lymphocyte Heterogeneity. Trends Immunol. 2019. [CrossRef] [PubMed]

5. Liu, S.; Dhar, P.; Wu, J.D. NK Cell Plasticity in Cancer. J. Clin. Med. 2019, 8, 1492. [CrossRef] [PubMed]

6. Elliott, J.M.; Yokoyama, W.M. Unifying concepts of MHC-dependent natural killer cell education. Trends Immunol. 2011, 32, 364-372. [CrossRef] [PubMed]

7. Freud, A.G.; Mundy-Bosse, B.L.; Yu, J.; Caligiuri, M.A. The Broad Spectrum of Human Natural Killer Cell Diversity. Immunity 2017, 47, 820-833. [CrossRef] [PubMed]

8. Parodi, M.; Pedrazzi, M.; Cantoni, C.; Averna, M.; Patrone, M.; Cavaletto, M.; Spertino, S.; Pende, D.; Balsamo, M.; Pietra, G.; et al. Natural Killer (NK)/melanoma cell interaction induces NK-mediated release of chemotactic High Mobility Group Box-1 (HMGB1) capable of amplifying NK cell recruitment. Oncoimmunology 2015, 4, e1052353. [CrossRef]

9. Handgretinger, R.; Lang, P.; Andre, M.C. Exploitation of natural killer cells for the treatment of acute leukemia. Blood 2016, 127, 3341-3349. [CrossRef]

10. Cooley, S.; Parham, P.; Miller, J.S. Strategies to activate NK cells to prevent relapse and induce remission following hematopoietic stem cell transplantation. Blood 2018, 131, 1053-1062. [CrossRef]

11. Locatelli, F.; Pende, D.; Falco, M.; Della Chiesa, M.; Moretta, A.; Moretta, L. NK Cells Mediate a Crucial Graft-versus-Leukemia Effect in Haploidentical-HSCT to Cure High-Risk Acute Leukemia. Trends Immunol. 2018, 39, 577-590. [CrossRef] [PubMed]

12. Miller, J.S.; Lanier, L.L. Natural Killer Cells in Cancer Immunotherapy. Annu. Rev. Cancer Biol. 2019, 3, 77-103. [CrossRef]

13. Rea, D.; Henry, G.; Khaznadar, Z.; Etienne, G.; Guilhot, F.; Nicolini, F.; Guilhot, J.; Rousselot, P.; Huguet, F.; Legros, L.; et al. Natural killer-cell counts are associated with molecular relapse-free survival after imatinib discontinuation in chronic myeloid leukemia: The IMMUNOSTIM study. Haematologica 2017, 102, 1368-1377. [CrossRef] [PubMed]

14. Ilander, M.; Olsson-Stromberg, U.; Schlums, H.; Guilhot, J.; Bruck, O.; Lahteenmaki, H.; Kasanen, T.; Koskenvesa, P.; Soderlund, S.; Hoglund, M.; et al. Increased proportion of mature NK cells is associated with successful imatinib discontinuation in chronic myeloid leukemia. Leukemia 2017, 31, 1108-1116. [CrossRef]

15. Moretta, A.; Bottino, C.; Vitale, M.; Pende, D.; Biassoni, R.; Mingari, M.C.; Moretta, L. Receptors for HLA class-I molecules in human natural killer cells. Annu. Rev. Immunol. 1996, 14, 619-648. [CrossRef]

16. Colonna, M.; Navarro, F.; Bellon, T.; Llano, M.; Garcia, P.; Samaridis, J.; Angman, L.; Cella, M.; Lopez-Botet, M. A common inhibitory receptor for major histocompatibility complex class I molecules on human lymphoid and myelomonocytic cells. J. Exp. Med. 1997, 186, 1809-1818. [CrossRef]

17. Parham, P. MHC class I molecules and KIRs in human history, health and survival. Nat. Rev. Immunol. 2005, 5, 201-214. [CrossRef]

18. Marsh, S.G.; Parham, P.; Dupont, B.; Geraghty, D.E.; Trowsdale, J.; Middleton, D.; Vilches, C.; Carrington, M.; Witt, C.; Guethlein, L.A.; et al. Killer-cell immunoglobulin-like receptor (KIR) nomenclature report, 2002. Hum. Immunol. 2003, 64, 648-654. [CrossRef] 
19. Biassoni, R.; Cantoni, C.; Falco, M.; Verdiani, S.; Bottino, C.; Vitale, M.; Conte, R.; Poggi, A.; Moretta, A.; Moretta, L. The human leukocyte antigen (HLA)-C-specific "activatory" or "inhibitory" natural killer cell receptors display highly homologous extracellular domains but differ in their transmembrane and intracytoplasmic portions. J. Exp. Med. 1996, 183, 645-650. [CrossRef]

20. Olcese, L.; Cambiaggi, A.; Semenzato, G.; Bottino, C.; Moretta, A.; Vivier, E. Human killer cell activatory receptors for MHC class I molecules are included in a multimeric complex expressed by natural killer cells. J. Immunol. 1997, 158, 5083-5086.

21. Lanier, L.L.; Corliss, B.C.; Wu, J.; Leong, C.; Phillips, J.H. Immunoreceptor DAP12 bearing a tyrosine-based activation motif is involved in activating NK cells. Nature 1998, 391, 703-707. [CrossRef] [PubMed]

22. Rajagopalan, S.; Long, E.O. KIR2DL4 (CD158d): An activation receptor for HLA-G. Front. Immunol. 2012, 3, 258. [CrossRef] [PubMed]

23. Martin, A.M.; Kulski, J.K.; Gaudieri, S.; Witt, C.S.; Freitas, E.M.; Trowsdale, J.; Christiansen, F.T. Comparative genomic analysis, diversity and evolution of two KIR haplotypes A and B. Gene 2004, 335, 121-131. [CrossRef] [PubMed]

24. Pyo, C.W.; Guethlein, L.A.; Vu, Q.; Wang, R.; Abi-Rached, L.; Norman, P.J.; Marsh, S.G.; Miller, J.S.; Parham, P.; Geraghty, D.E. Different patterns of evolution in the centromeric and telomeric regions of group A and B haplotypes of the human killer cell Ig-like receptor locus. PLoS ONE 2010, 5, e15115. [CrossRef] [PubMed]

25. Moretta, A.; Sivori, S.; Vitale, M.; Pende, D.; Morelli, L.; Augugliaro, R.; Bottino, C.; Moretta, L. Existence of both inhibitory (p58) and activatory (p50) receptors for HLA-C molecules in human natural killer cells. J. Exp. Med. 1995, 182, 875-884. [CrossRef]

26. Pende, D.; Falco, M.; Vitale, M.; Cantoni, C.; Vitale, C.; Munari, E.; Bertaina, A.; Moretta, F.; Del Zotto, G.; Pietra, G.; et al. Killer Ig-Like Receptors (KIRs): Their Role in NK Cell Modulation and Developments Leading to Their Clinical Exploitation. Front. Immunol. 2019, 10, 1179. [CrossRef]

27. Braud, V.M.; Allan, D.S.; O'Callaghan, C.A.; Soderstrom, K.; D'Andrea, A.; Ogg, G.S.; Lazetic, S.; Young, N.T.; Bell, J.I.; Phillips, J.H.; et al. HLA-E binds to natural killer cell receptors CD94/NKG2A, B and C. Nature 1998, 391, 795-799. [CrossRef]

28. Horowitz, A.; Djaoud, Z.; Nemat-Gorgani, N.; Blokhuis, J.; Hilton, H.G.; Beziat, V.; Malmberg, K.J.; Norman, P.J.; Guethlein, L.A.; Parham, P. Class I HLA haplotypes form two schools that educate NK cells in different ways. Sci. Immunol. 2016, 1, 1672. [CrossRef]

29. Hallner, A.; Bernson, E.; Hussein, B.A.; Ewald Sander, F.; Brune, M.; Aurelius, J.; Martner, A.; Hellstrand, K.; Thoren, F.B. The HLA-B -21 dimorphism impacts on NK cell education and clinical outcome of immunotherapy in acute myeloid leukemia. Blood 2019, 133, 1479-1488. [CrossRef]

30. Trinchieri, G. Biology of natural killer cells. Adv. Immunol. 1989, 47, 187-376.

31. Moretta, A.; Bottino, C.; Vitale, M.; Pende, D.; Cantoni, C.; Mingari, M.C.; Biassoni, R.; Moretta, L. Activating receptors and coreceptors involved in human natural killer cell-mediated cytolysis. Annu. Rev. Immunol. 2001, 19, 197-223. [CrossRef] [PubMed]

32. Sivori, S.; Vitale, M.; Morelli, L.; Sanseverino, L.; Augugliaro, R.; Bottino, C.; Moretta, L.; Moretta, A. p46, a novel natural killer cell-specific surface molecule that mediates cell activation. J. Exp. Med. 1997, 186, 1129-1136. [CrossRef] [PubMed]

33. Pessino, A.; Sivori, S.; Bottino, C.; Malaspina, A.; Morelli, L.; Moretta, L.; Biassoni, R.; Moretta, A. Molecular Cloning of NKp46: A Novel Member of the Immunoglobulin Superfamily Involved in Triggering of Natural Cytotoxicity. J. Exp. Med. 1998, 188, 953-960. [CrossRef] [PubMed]

34. Vitale, M.; Bottino, C.; Sivori, S.; Sanseverino, L.; Castriconi, R.; Marcenaro, E.; Augugliaro, R.; Moretta, L.; Moretta, A. NKp44, a novel triggering surface molecule specifically expressed by activated natural killer cells, is involved in non-major histocompatibility complex-restricted tumor cell lysis. J. Exp. Med. 1998, 187, 2065-2072. [CrossRef] [PubMed]

35. Cantoni, C.; Bottino, C.; Vitale, M.; Pessino, A.; Augugliaro, R.; Malaspina, A.; Parolini, S.; Moretta, L.; Moretta, A.; Biassoni, R. NKp44, A Triggering Receptor Involved in Tumor Cell Lysis by Activated Human Natural Killer Cells, Is a Novel Member of the Immunoglobulin Superfamily. J. Exp. Med. 1999, 189, 787-796. [CrossRef] [PubMed] 
36. Pende, D.; Parolini, S.; Pessino, A.; Sivori, S.; Augugliaro, R.; Morelli, L.; Marcenaro, E.; Accame, L.; Malaspina, A.; Biassoni, R.; et al. Identification and molecular characterization of NKp30, a novel triggering receptor involved in natural cytotoxicity mediated by human natural killer cells. J. Exp. Med. 1999, 190, 1505-1516. [CrossRef] [PubMed]

37. Campbell, K.S.; Yusa, S.; Kikuchi-Maki, A.; Catina, T.L. NKp44 triggers NK cell activation through DAP12 association that is not influenced by a putative cytoplasmic inhibitory sequence. J. Immunol. 2004, 172, 899-906. [CrossRef]

38. Chiossone, L.; Dumas, P.Y.; Vienne, M.; Vivier, E. Natural killer cells and other innate lymphoid cells in cancer. Nat. Rev. Immunol. 2018, 18, 671-688. [CrossRef]

39. Parodi, M.; Favoreel, H.; Candiano, G.; Gaggero, S.; Sivori, S.; Mingari, M.C.; Moretta, L.; Vitale, M.; Cantoni, C. NKp44-NKp44 Ligand Interactions in the Regulation of Natural Killer Cells and Other Innate Lymphoid Cells in Humans. Front. Immunol. 2019, 10, 719. [CrossRef]

40. Correia, D.V.; Fogli, M.; Hudspeth, K.; da Silva, M.G.; Mavilio, D.; Silva-Santos, B. Differentiation of human peripheral blood Vdelta1+ T cells expressing the natural cytotoxicity receptor NKp30 for recognition of lymphoid leukemia cells. Blood 2011, 118, 992-1001. [CrossRef]

41. Pievani, A.; Borleri, G.; Pende, D.; Moretta, L.; Rambaldi, A.; Golay, J.; Introna, M. Dual-functional capability of CD3+CD56+ CIK cells, a T-cell subset that acquires NK function and retains TCR-mediated specific cytotoxicity. Blood 2011, 118, 3301-3310. [CrossRef] [PubMed]

42. Correia, M.P.; Stojanovic, A.; Bauer, K.; Juraeva, D.; Tykocinski, L.O.; Lorenz, H.M.; Brors, B.; Cerwenka, A. Distinct human circulating NKp30(+)FcepsilonRI $\gamma(+) \mathrm{CD} 8(+) \mathrm{T}$ cell population exhibiting high natural killer-like antitumor potential. Proc. Natl. Acad. Sci. USA 2018, 115, E5980-E5989. [CrossRef] [PubMed]

43. Pende, D.; Spaggiari, G.M.; Marcenaro, S.; Martini, S.; Rivera, P.; Capobianco, A.; Falco, M.; Lanino, E.; Pierri, I.; Zambello, R.; et al. Analysis of the receptor-ligand interactions in the natural killer-mediated lysis of freshly isolated myeloid or lymphoblastic leukemias: Evidence for the involvement of the Poliovirus receptor (CD155) and Nectin-2 (CD112). Blood 2005, 105, 2066-2073. [CrossRef] [PubMed]

44. Barrow, A.D.; Martin, C.J.; Colonna, M. The Natural Cytotoxicity Receptors in Health and Disease. Front. Immunol. 2019, 10, 909. [CrossRef] [PubMed]

45. Vitale, M.; Cantoni, C.; Della Chiesa, M.; Ferlazzo, G.; Carlomagno, S.; Pende, D.; Falco, M.; Pessino, A.; Muccio, L.; De Maria, A.; et al. An Historical Overview: The Discovery of How NK Cells Can Kill Enemies, Recruit Defense Troops, and More. Front. Immunol. 2019, 10, 1415. [CrossRef] [PubMed]

46. Brandt, C.S.; Baratin, M.; Yi, E.C.; Kennedy, J.; Gao, Z.; Fox, B.; Haldeman, B.; Ostrander, C.D.; Kaifu, T.; Chabannon, C.; et al. The B7 family member B7-H6 is a tumor cell ligand for the activating natural killer cell receptor NKp30 in humans. J. Exp. Med. 2009, 206, 1495-1503. [CrossRef] [PubMed]

47. Baychelier, F.; Sennepin, A.; Ermonval, M.; Dorgham, K.; Debre, P.; Vieillard, V. Identification of a cellular ligand for the natural cytotoxicity receptor NKp44. Blood 2013, 122, 2935-2942. [CrossRef] [PubMed]

48. Niehrs, A.; Garcia-Beltran, W.F.; Norman, P.J.; Watson, G.M.; Holzemer, A.; Chapel, A.; Richert, L.; Pommerening-Roser, A.; Korner, C.; Ozawa, M.; et al. A subset of HLA-DP molecules serve as ligands for the natural cytotoxicity receptor NKp44. Nat. Immunol. 2019. [CrossRef]

49. Rosental, B.; Brusilovsky, M.; Hadad, U.; Oz, D.; Appel, M.Y.; Afergan, F.; Yossef, R.; Rosenberg, L.A.; Aharoni, A.; Cerwenka, A.; et al. Proliferating cell nuclear antigen is a novel inhibitory ligand for the natural cytotoxicity receptor NKp44. J. Immunol. 2011, 187, 5693-5702. [CrossRef]

50. Pogge von Strandmann, E.; Simhadri, V.R.; von Tresckow, B.; Sasse, S.; Reiners, K.S.; Hansen, H.P.; Rothe, A.; Boll, B.; Simhadri, V.L.; Borchmann, P.; et al. Human leukocyte antigen-B-associated transcript 3 is released from tumor cells and engages the NKp30 receptor on natural killer cells. Immunity 2007, 27, 965-974. [CrossRef]

51. Schlecker, E.; Fiegler, N.; Arnold, A.; Altevogt, P.; Rose-John, S.; Moldenhauer, G.; Sucker, A.; Paschen, A.; von Strandmann, E.P.; Textor, S.; et al. Metalloprotease-Mediated Tumor Cell Shedding of B7-H6, the Ligand of the Natural Killer Cell-Activating Receptor NKp30. Cancer Res. 2014, 74, 3429-3440. [CrossRef] [PubMed]

52. Narni-Mancinelli, E.; Gauthier, L.; Baratin, M.; Guia, S.; Fenis, A.; Deghmane, A.E.; Rossi, B.; Fourquet, P.; Escaliere, B.; Kerdiles, Y.M.; et al. Complement factor $\mathrm{P}$ is a ligand for the natural killer cell-activating receptor NKp46. Sci. Immunol. 2017, 2. [CrossRef] [PubMed] 
53. Barrow, A.D.; Edeling, M.A.; Trifonov, V.; Luo, J.; Goyal, P.; Bohl, B.; Bando, J.K.; Kim, A.H.; Walker, J.; Andahazy, M.; et al. Natural Killer Cells Control Tumor Growth by Sensing a Growth Factor. Cell 2018, 172, 534-548. [CrossRef] [PubMed]

54. Gaggero, S.; Bruschi, M.; Petretto, A.; Parodi, M.; Del Zotto, G.; Lavarello, C.; Prato, C.; Santucci, L.; Barbuto, A.; Bottino, C.; et al. Nidogen-1 is a novel extracellular ligand for the NKp44 activating receptor. Oncoimmunology 2018, 7, e1470730. [CrossRef] [PubMed]

55. Reiners, K.S.; Topolar, D.; Henke, A.; Simhadri, V.R.; Kessler, J.; Sauer, M.; Bessler, M.; Hansen, H.P.; Tawadros, S.; Herling, M.; et al. Soluble ligands for NK cell receptors promote evasion of chronic lymphocytic leukemia cells from NK cell anti-tumor activity. Blood 2013, 121, 3658-3665. [CrossRef] [PubMed]

56. Sivori, S.; Pende, D.; Bottino, C.; Marcenaro, E.; Pessino, A.; Biassoni, R.; Moretta, L.; Moretta, A. NKp46 is the major triggering receptor involved in the natural cytotoxicity of fresh or cultured human NK cells. Correlation between surface density of NKp46 and natural cytotoxicity against autologous, allogeneic or xenogeneic target cells. Eur. J. Immunol. 1999, 29, 1656-1666. [CrossRef]

57. Costello, R.T.; Sivori, S.; Marcenaro, E.; Lafage-Pochitaloff, M.; Mozziconacci, M.J.; Reviron, D.; Gastaut, J.A.; Pende, D.; Olive, D.; Moretta, A. Defective expression and function of natural killer cell-triggering receptors in patients with acute myeloid leukemia. Blood 2002, 99, 3661-3667. [CrossRef]

58. Fauriat, C.; Just-Landi, S.; Mallet, F.; Arnoulet, C.; Sainty, D.; Olive, D.; Costello, R.T. Deficient expression of NCR in NK cells from acute myeloid leukemia: Evolution during leukemia treatment and impact of leukemia cells in NCRdull phenotype induction. Blood 2007, 109, 323-330. [CrossRef]

59. Costello, R.T.; Knoblauch, B.; Sanchez, C.; Mercier, D.; Le Treut, T.; Sébahoun, G. Expression of natural killer cell activating receptors in patients with chronic lymphocytic leukaemia. Immunology 2012, 135, 151-157. [CrossRef]

60. Della Chiesa, M.; Carlomagno, S.; Frumento, G.; Balsamo, M.; Cantoni, C.; Conte, R.; Moretta, L.; Moretta, A.; Vitale, M. The tryptophan catabolite L-kynurenine inhibits the surface expression of NKp46and NKG2D-activating receptors and regulates NK-cell function. Blood 2006, 108, 4118-4125. [CrossRef]

61. Castriconi, R.; Dondero, A.; Bellora, F.; Moretta, L.; Castellano, A.; Locatelli, F.; Corrias, M.V.; Moretta, A.; Bottino, C. Neuroblastoma-derived TGF-beta1 modulates the chemokine receptor repertoire of human resting NK cells. J. Immunol. 2013, 190, 5321-5328. [CrossRef] [PubMed]

62. Spaggiari, G.M.; Capobianco, A.; Abdelrazik, H.; Becchetti, F.; Mingari, M.C.; Moretta, L. Mesenchymal stem cells inhibit natural killer-cell proliferation, cytotoxicity, and cytokine production: Role of indoleamine 2,3-dioxygenase and prostaglandin E2. Blood 2008, 111, 1327-1333. [CrossRef] [PubMed]

63. Stabile, H.; Fionda, C.; Gismondi, A.; Santoni, A. Role of Distinct Natural Killer Cell Subsets in Anticancer Response. Front. Immunol. 2017, 8, 293. [CrossRef] [PubMed]

64. Gao, Y.; Souza-Fonseca-Guimaraes, F.; Bald, T.; Ng, S.S.; Young, A.; Ngiow, S.F.; Rautela, J.; Straube, J.; Waddell, N.; Blake, S.J.; et al. Tumor immunoevasion by the conversion of effector NK cells into type 1 innate lymphoid cells. Nat. Immunol. 2017, 18, 1004-1015. [CrossRef] [PubMed]

65. Raulet, D.H.; Gasser, S.; Gowen, B.G.; Deng, W.; Jung, H. Regulation of ligands for the NKG2D activating receptor. Annu. Rev. Immunol. 2013, 31, 413-441. [CrossRef] [PubMed]

66. Groh, V.; Bahram, S.; Bauer, S.; Herman, A.; Beauchamp, M.; Spies, T. Cell stress-regulated human major histocompatibility complex class I gene expressed in gastrointestinal epithelium. Proc. Natl. Acad. Sci. USA 1996, 93, 12445-12450. [CrossRef]

67. Pende, D.; Rivera, P.; Marcenaro, S.; Chang, C.C.; Biassoni, R.; Conte, R.; Kubin, M.; Cosman, D.; Ferrone, S.; Moretta, L.; et al. Major histocompatibility complex class I-related chain A and UL16-binding protein expression on tumor cell lines of different histotypes: Analysis of tumor susceptibility to NKG2D-dependent natural killer cell cytotoxicity. Cancer Res. 2002, 62, 6178-6186.

68. Hilpert, J.; Grosse-Hovest, L.; Grünebach, F.; Buechele, C.; Nuebling, T.; Raum, T.; Steinle, A.; Salih, H.R. Comprehensive Analysis of NKG2D Ligand Expression and Release in Leukemia: Implications for NKG2D-Mediated NK Cell Responses. J. Immunol. 2012, 189, 1360-1371. [CrossRef]

69. Torelli, G.F.; Peragine, N.; Raponi, S.; Pagliara, D.; De Propris, M.S.; Vitale, A.; Bertaina, A.; Barberi, W.; Moretta, L.; Basso, G.; et al. Recognition of adult and pediatric acute lymphoblastic leukemia blasts by natural killer cells. Haematologica 2014, 99, 1248-1254. [CrossRef] 
70. Shibuya, A.; Campbell, D.; Hannum, C.; Yssel, H.; Franz-Bacon, K.; McClanahan, T.; Kitamura, T.; Nicholl, J.; Sutherland, G.R.; Lanier, L.L.; et al. DNAM-1, a novel adhesion molecule involved in the cytolytic function of T lymphocytes. Immunity 1996, 4, 573-581. [CrossRef]

71. Sivori, S.; Parolini, S.; Falco, M.; Marcenaro, E.; Biassoni, R.; Bottino, C.; Moretta, L.; Moretta, A. 2 B4 functions as a co-receptor in human NK cell activation. Eur. J. Immunol. 2000, 30, 787-793. [CrossRef]

72. Bottino, C.; Falco, M.; Parolini, S.; Marcenaro, E.; Augugliaro, R.; Sivori, S.; Landi, E.; Biassoni, R.; Notarangelo, L.D.; Moretta, L.; et al. NTB-A [correction of GNTB-A], a novel SH2D1A-associated surface molecule contributing to the inability of natural killer cells to kill Epstein-Barr virus-infected B cells in X-linked lymphoproliferative disease. J. Exp. Med. 2001, 194, 235-246. [CrossRef] [PubMed]

73. Marcenaro, E.; Augugliaro, R.; Falco, M.; Castriconi, R.; Parolini, S.; Sivori, S.; Romeo, E.; Millo, R.; Moretta, L.; Bottino, C.; et al. CD59 is physically and functionally associated with natural cytotoxicity receptors and activates human NK cell-mediated cytotoxicity. Eur. J. Immunol. 2003, 33, 3367-3376. [CrossRef] [PubMed]

74. Vitale, M.; Falco, M.; Castriconi, R.; Parolini, S.; Zambello, R.; Semenzato, G.; Biassoni, R.; Bottino, C.; Moretta, L.; Moretta, A. Identification of NKp80, a novel triggering molecule expressed by human NK cells. Eur. J. Immunol. 2001, 31, 233-242. [CrossRef]

75. Bottino, C.; Castriconi, R.; Pende, D.; Rivera, P.; Nanni, M.; Carnemolla, B.; Cantoni, C.; Grassi, J.; Marcenaro, S.; Reymond, N.; et al. Identification of PVR (CD155) and Nectin-2 (CD112) as cell surface ligands for the human DNAM-1 (CD226) activating molecule. J. Exp. Med. 2003, 198, 557-567. [CrossRef] [PubMed]

76. McArdel, S.L.; Terhorst, C.; Sharpe, A.H. Roles of CD48 in regulating immunity and tolerance. Clin. Immunol. 2016, 164, 10-20. [CrossRef] [PubMed]

77. Sivori, S.; Falco, M.; Carlomagno, S.; Romeo, E.; Moretta, L.; Moretta, A. Heterogeneity of TLR3 mRNA transcripts and responsiveness to poly (I:C) in human NK cells derived from different donors. Int. Immunol. 2007, 19, 1341-1348. [CrossRef]

78. Sivori, S.; Falco, M.; Carlomagno, S.; Romeo, E.; Soldani, C.; Bensussan, A.; Viola, A.; Moretta, L.; Moretta, A. A novel KIR-associated function: Evidence that CpG DNA uptake and shuttling to early endosomes is mediated by KIR3DL2. Blood 2010, 116, 1637-1647. [CrossRef]

79. Chiossone, L.; Vienne, M.; Kerdiles, Y.M.; Vivier, E. Natural killer cell immunotherapies against cancer: Checkpoint inhibitors and more. Semin. Immunol. 2017, 31, 55-63. [CrossRef]

80. Sivori, S.; Vacca, P.; Del Zotto, G.; Munari, E.; Mingari, M.C.; Moretta, L. Human NK cells: Surface receptors, inhibitory checkpoints, and translational applications. Cell Mol. Immunol. 2019, 16, 430-441. [CrossRef]

81. Guan, J.; Wang, R.; Hasan, S.; Tao, L.; Wazir, M.; Jain, A.G.; Zhu, X.; Perkins, S.; Mohamed, S.; Chang, C.C.; et al. Prognostic Significance of the Dynamic Change of Programmed Death-ligand 1 Expression in Patients with Multiple Myeloma. Cureus 2019, 11, e4401. [CrossRef] [PubMed]

82. Pesce, S.; Greppi, M.; Tabellini, G.; Rampinelli, F.; Parolini, S.; Olive, D.; Moretta, L.; Moretta, A.; Marcenaro, E. Identification of a subset of human natural killer cells expressing high levels of programmed death 1 : A phenotypic and functional characterization. J. Allergy Clin. Immunol. 2017, 139, 335-346. [CrossRef] [PubMed]

83. Pesce, S.; Greppi, M.; Grossi, F.; Del Zotto, G.; Moretta, L.; Sivori, S.; Genova, C.; Marcenaro, E. PD/1-PD-Ls Checkpoint: Insight on the Potential Role of NK Cells. Front. Immunol. 2019, 10, 1242. [CrossRef] [PubMed]

84. Dong, H.; Strome, S.E.; Salomao, D.R.; Tamura, H.; Hirano, F.; Flies, D.B.; Roche, P.C.; Lu, J.; Zhu, G.; Tamada, K.; et al. Tumor-associated B7-H1 promotes T-cell apoptosis: A potential mechanism of immune evasion. Nat. Med. 2002, 8, 793-800. [CrossRef] [PubMed]

85. Hobo, W.; Hutten, T.J.A.; Schaap, N.P.M.; Dolstra, H. Immune checkpoint molecules in acute myeloid leukaemia: Managing the double-edged sword. Br. J. Haematol. 2018, 181, 38-53. [CrossRef] [PubMed]

86. Dougall, W.C.; Kurtulus, S.; Smyth, M.J.; Anderson, A.C. TIGIT and CD96: New checkpoint receptor targets for cancer immunotherapy. Immunol. Rev. 2017, 276, 112-120. [CrossRef]

87. Zhou, X.M.; Li, W.Q.; Wu, Y.H.; Han, L.; Cao, X.G.; Yang, X.M.; Wang, H.F.; Zhao, W.S.; Zhai, W.J.; Qi, Y.M.; et al. Intrinsic Expression of Immune Checkpoint Molecule TIGIT Could Help Tumor Growth in vivo by Suppressing the Function of NK and CD8(+) T Cells. Front. Immunol. 2018, 9, 2821. [CrossRef]

88. Zhang, Q.; Bi, J.; Zheng, X.; Chen, Y.; Wang, H.; Wu, W.; Wang, Z.; Wu, Q.; Peng, H.; Wei, H.; et al. Blockade of the checkpoint receptor TIGIT prevents NK cell exhaustion and elicits potent anti-tumor immunity. Nat. Immunol. 2018, 19, 723-732. [CrossRef] 
89. da Silva, I.P.; Gallois, A.; Jimenez-Baranda, S.; Khan, S.; Anderson, A.C.; Kuchroo, V.K.; Osman, I.; Bhardwaj, N. Reversal of NK-cell exhaustion in advanced melanoma by Tim-3 blockade. Cancer Immunol. Res. 2014, 2, 410-422. [CrossRef]

90. Huard, B.; Tournier, M.; Triebel, F. LAG-3 does not define a specific mode of natural killing in human. Immunol. Lett. 1998, 61, 109-112. [CrossRef]

91. Miyazaki, T.; Dierich, A.; Benoist, C.; Mathis, D. Independent modes of natural killing distinguished in mice lacking Lag3. Science 1996, 272, 405-408. [CrossRef]

92. Zhu, C.; Anderson, A.C.; Schubart, A.; Xiong, H.; Imitola, J.; Khoury, S.J.; Zheng, X.X.; Strom, T.B.; Kuchroo, V.K. The Tim-3 ligand galectin-9 negatively regulates T helper type 1 immunity. Nat. Immunol. 2005, 6, 1245-1252. [CrossRef] [PubMed]

93. Nakayama, M.; Akiba, H.; Takeda, K.; Kojima, Y.; Hashiguchi, M.; Azuma, M.; Yagita, H.; Okumura, K. Tim-3 mediates phagocytosis of apoptotic cells and cross-presentation. Blood 2009, 113, 3821-3830. [CrossRef] [PubMed]

94. Chiba, S.; Baghdadi, M.; Akiba, H.; Yoshiyama, H.; Kinoshita, I.; Dosaka-Akita, H.; Fujioka, Y.; Ohba, Y.; Gorman, J.V.; Colgan, J.D.; et al. Tumor-infiltrating DCs suppress nucleic acid-mediated innate immune responses through interactions between the receptor TIM-3 and the alarmin HMGB1. Nat. Immunol. 2012, 13, 832-842. [CrossRef] [PubMed]

95. Huang, Y.H.; Zhu, C.; Kondo, Y.; Anderson, A.C.; Gandhi, A.; Russell, A.; Dougan, S.K.; Petersen, B.S.; Melum, E.; Pertel, T.; et al. CEACAM1 regulates TIM-3-mediated tolerance and exhaustion. Nature 2015, 517, 386-390. [CrossRef] [PubMed]

96. Bialoszewska, A.; Malejczyk, J. Biological and Clinical Significance of Human NKRP1A/LLT1 Receptor/Ligand Interactions. Crit. Rev. Immunol. 2018, 38, 479-489. [CrossRef]

97. Germain, C.; Guillaudeux, T.; Galsgaard, E.D.; Hervouet, C.; Tekaya, N.; Gallouet, A.S.; Fassy, J.; Bihl, F.; Poupon, G.; Lazzari, A.; et al. Lectin-like transcript 1 is a marker of germinal center-derived B-cell non-Hodgkin's lymphomas dampening natural killer cell functions. Oncoimmunology 2015, 4, e1026503. [CrossRef]

98. Poggi, A.; Costa, P.; Tomasello, E.; Moretta, L. IL-12-induced up-regulation of NKRP1A expression in human NK cells and consequent NKRP1A-mediated down-regulation of NK cell activation. Eur. J. Immunol. 1998, 28, 1611-1616. [CrossRef]

99. Azzoni, L.; Zatsepina, O.; Abebe, B.; Bennett, I.M.; Kanakaraj, P.; Perussia, B. Differential transcriptional regulation of CD161 and a novel gene, 197/15a, by IL-2, IL-15, and IL-12 in NK and T cells. J. Immunol. 1998, 161, 3493-3500.

100. Rocha, V.; Locatelli, F. Searching for alternative hematopoietic stem cell donors for pediatric patients. Bone Marrow Transplant. 2007, 41, 207-214. [CrossRef]

101. Aversa, F.; Tabilio, A.; Velardi, A.; Cunningham, I.; Terenzi, A.; Falzetti, F.; Ruggeri, L.; Barbabietola, G.; Aristei, C.; Latini, P.; et al. Treatment of high-risk acute leukemia with T-cell-depleted stem cells from related donors with one fully mismatched HLA haplotype. N. Engl. J. Med. 1998, 339, 1186-1193. [CrossRef] [PubMed]

102. Ruggeri, L.; Capanni, M.; Urbani, E.; Perruccio, K.; Shlomchik, W.D.; Tosti, A.; Posati, S.; Rogaia, D.; Frassoni, F.; Aversa, F.; et al. Effectiveness of donor natural killer cell alloreactivity in mismatched hematopoietic transplants. Science 2002, 295, 2097-2100. [CrossRef] [PubMed]

103. Ruggeri, L.; Mancusi, A.; Capanni, M.; Urbani, E.; Carotti, A.; Aloisi, T.; Stern, M.; Pende, D.; Perruccio, K.; Burchielli, E.; et al. Donor natural killer cell allorecognition of missing self in haploidentical hematopoietic transplantation for acute myeloid leukemia: Challenging its predictive value. Blood 2007, 110, 433-440. [CrossRef] [PubMed]

104. Reisner, Y.; Hagin, D.; Martelli, M.F. Haploidentical hematopoietic transplantation: Current status and future perspectives. Blood 2011, 118, 6006-6017. [CrossRef] [PubMed]

105. Nguyen, S.; Dhedin, N.; Vernant, J.P.; Kuentz, M.; Al Jijakli, A.; Rouas-Freiss, N.; Carosella, E.D.; Boudifa, A.; Debre, P.; Vieillard, V. NK-cell reconstitution after haploidentical hematopoietic stem-cell transplantations: Immaturity of NK cells and inhibitory effect of NKG2A override GvL effect. Blood 2005, 105, 4135-4142. [CrossRef] 
106. Pende, D.; Marcenaro, S.; Falco, M.; Martini, S.; Bernardo, M.E.; Montagna, D.; Romeo, E.; Cognet, C.; Martinetti, M.; Maccario, R.; et al. Anti-leukemia activity of alloreactive NK cells in KIR ligand-mismatched haploidentical HSCT for pediatric patients: Evaluation of the functional role of activating KIR and redefinition of inhibitory KIR specificity. Blood 2009, 113, 3119-3129. [CrossRef]

107. Luznik, L.; O’Donnell, P.V.; Fuchs, E.J. Post-transplantation cyclophosphamide for tolerance induction in HLA-haploidentical bone marrow transplantation. Semin. Oncol. 2012, 39, 683-693. [CrossRef]

108. Russo, A.; Oliveira, G.; Berglund, S.; Greco, R.; Gambacorta, V.; Cieri, N.; Toffalori, C.; Zito, L.; Lorentino, F.; Piemontese, S.; et al. NK cell recovery after haploidentical HSCT with posttransplant cyclophosphamide: Dynamics and clinical implications. Blood 2018, 131, 247-262. [CrossRef]

109. Shimoni, A.; Labopin, M.; Lorentino, F.; Van Lint, M.T.; Koc, Y.; Gulbas, Z.; Tischer, J.; Bruno, B.; Blaise, D.; Pioltelli, P.; et al. Killer cell immunoglobulin-like receptor ligand mismatching and outcome after haploidentical transplantation with post-transplant cyclophosphamide. Leukemia 2019, 33, 230-239. [CrossRef]

110. Veluchamy, J.P.; Kok, N.; van der Vliet, H.J.; Verheul, H.M.W.; de Gruijl, T.D.; Spanholtz, J. The Rise of Allogeneic Natural Killer Cells as a Platform for Cancer Immunotherapy: Recent Innovations and Future Developments. Front. Immunol. 2017, 8, 631. [CrossRef]

111. Van Elssen, C.; Ciurea, S.O. NK cell therapy after hematopoietic stem cell transplantation: Can we improve anti-tumor effect? Int. J. Hematol. 2018, 107, 151-156. [CrossRef] [PubMed]

112. Lupo, K.B.; Matosevic, S. Natural Killer Cells as Allogeneic Effectors in Adoptive Cancer Immunotherapy. Cancers 2019, 11, 769. [CrossRef] [PubMed]

113. Passweg, J.R.; Tichelli, A.; Meyer-Monard, S.; Heim, D.; Stern, M.; Kühne, T.; Favre, G.; Gratwohl, A. Purified donor NK-lymphocyte infusion to consolidate engraftment after haploidentical stem cell transplantation. Leukemia 2004, 18, 1835-1838. [CrossRef] [PubMed]

114. Stern, M.; Passweg, J.R.; Meyer-Monard, S.; Esser, R.; Tonn, T.; Soerensen, J.; Paulussen, M.; Gratwohl, A.; Klingebiel, T.; Bader, P.; et al. Pre-emptive immunotherapy with purified natural killer cells after haploidentical SCT: A prospective phase II study in two centers. Bone Marrow Transplant. 2013, 48, 433-438. [CrossRef]

115. Killig, M.; Friedrichs, B.; Meisig, J.; Gentilini, C.; Bluthgen, N.; Loddenkemper, C.; Labopin, M.; Basara, N.; Pfrepper, C.; Niederwieser, D.W.; et al. Tracking in vivo dynamics of NK cells transferred in patients undergoing stem cell transplantation. Eur. J. Immunol. 2014, 44, 2822-2834. [CrossRef]

116. Jaiswal, S.R.; Zaman, S.; Nedunchezhian, M.; Chakrabarti, A.; Bhakuni, P.; Ahmed, M.; Sharma, K.; Rawat, S.; O'Donnell, P.; Chakrabarti, S. CD56-enriched donor cell infusion after post-transplantation cyclophosphamide for haploidentical transplantation of advanced myeloid malignancies is associated with prompt reconstitution of mature natural killer cells and regulatory T cells with reduced incidence of acute graft versus host disease: A pilot study. Cytotherapy 2017, 19, 531-542. [CrossRef]

117. Ciurea, S.O.; Schafer, J.R.; Bassett, R.; Denman, C.J.; Cao, K.; Willis, D.; Rondon, G.; Chen, J.; Soebbing, D.; Kaur, I.; et al. Phase 1 clinical trial using mbIL21 ex vivo-expanded donor-derived NK cells after haploidentical transplantation. Blood 2017, 130, 1857-1868. [CrossRef]

118. Brehm, C.; Huenecke, S.; Quaiser, A.; Esser, R.; Bremm, M.; Kloess, S.; Soerensen, J.; Kreyenberg, H.; Seidl, C.; Becker, P.S.; et al. IL-2 stimulated but not unstimulated NK cells induce selective disappearance of peripheral blood cells: Concomitant results to a phase I/II study. PLoS ONE 2011, 6, e27351. [CrossRef]

119. Koehl, U.; Kalberer, C.; Spanholtz, J.; Lee, D.A.; Miller, J.S.; Cooley, S.; Lowdell, M.; Uharek, L.; Klingemann, H.; Curti, A.; et al. Advances in clinical NK cell studies: Donor selection, manufacturing and quality control. Oncoimmunology 2016, 5, e1115178. [CrossRef]

120. Handgretinger, R. New approaches to graft engineering for haploidentical bone marrow transplantation. Semin. Oncol. 2012, 39, 664-673. [CrossRef]

121. Bethge, W.A.; Haegele, M.; Faul, C.; Lang, P.; Schumm, M.; Bornhauser, M.; Handgretinger, R.; Kanz, L. Haploidentical allogeneic hematopoietic cell transplantation in adults with reduced-intensity conditioning and CD3/CD19 depletion: Fast engraftment and low toxicity. Exp. Hematol. 2006, 34, 1746-1752. [CrossRef] [PubMed]

122. Lang, P.; Teltschik, H.M.; Feuchtinger, T.; Muller, I.; Pfeiffer, M.; Schumm, M.; Ebinger, M.; Schwarze, C.P.; Gruhn, B.; Schrauder, A.; et al. Transplantation of CD3/CD19 depleted allografts from haploidentical family donors in paediatric leukaemia. Br. J. Haematol. 2014, 165, 688-698. [CrossRef] [PubMed] 
123. Bertaina, A.; Merli, P.; Rutella, S.; Pagliara, D.; Bernardo, M.E.; Masetti, R.; Pende, D.; Falco, M.; Handgretinger, R.; Moretta, F.; et al. HLA-haploidentical stem cell transplantation after removal of $\alpha \beta+\mathrm{T}$ and B cells in children with nonmalignant disorders. Blood 2014, 124, 822-826. [CrossRef] [PubMed]

124. Li Pira, G.; Malaspina, D.; Girolami, E.; Biagini, S.; Cicchetti, E.; Conflitti, G.; Broglia, M.; Ceccarelli, S.; Lazzaro, S.; Pagliara, D.; et al. Selective Depletion of $\alpha \beta$ T Cells and B Cells for Human Leukocyte Antigen-Haploidentical Hematopoietic Stem Cell Transplantation. A Three-Year Follow-Up of Procedure Efficiency. Biol. Blood Marrow Transplant. 2016, 22, 2056-2064. [CrossRef]

125. Airoldi, I.; Bertaina, A.; Prigione, I.; Zorzoli, A.; Pagliara, D.; Cocco, C.; Meazza, R.; Loiacono, F.; Lucarelli, B.; Bernardo, M.E.; et al. gammadelta T cell reconstitution after HLA-haploidentical hematopoietic transplantation depleted of TCR- $\alpha \beta+/ C D 19+$ lymphocytes. Blood 2015. [CrossRef]

126. Locatelli, F.; Merli, P.; Pagliara, D.; Li Pira, G.; Falco, M.; Pende, D.; Rondelli, R.; Lucarelli, B.; Brescia, L.P.; Masetti, R.; et al. Outcome of children with acute leukemia given HLA-haploidentical HSCT after $\alpha \beta$ T-cell and B-cell depletion. Blood 2017, 130, 677-685. [CrossRef]

127. Cooley, S.; Weisdorf, D.J.; Guethlein, L.A.; Klein, J.P.; Wang, T.; Le, C.T.; Marsh, S.G.; Geraghty, D.; Spellman, S.; Haagenson, M.D.; et al. Donor selection for natural killer cell receptor genes leads to superior survival after unrelated transplantation for acute myelogenous leukemia. Blood 2010, 116, 2411-2419. [CrossRef]

128. Moretta, L.; Locatelli, F.; Pende, D.; Marcenaro, E.; Mingari, M.C.; Moretta, A. Killer Ig-like receptor-mediated control of natural killer cell alloreactivity in haploidentical hematopoietic stem cell transplantation. Blood 2011, 117, 764-771. [CrossRef]

129. Oevermann, L.; Michaelis, S.U.; Mezger, M.; Lang, P.; Toporski, J.; Bertaina, A.; Zecca, M.; Moretta, L.; Locatelli, F.; Handgretinger, R. KIR B haplotype donors confer a reduced risk for relapse after haploidentical transplantation in children with ALL. Blood 2014, 124, 2744-2747. [CrossRef]

130. Venstrom, J.M.; Pittari, G.; Gooley, T.A.; Chewning, J.H.; Spellman, S.; Haagenson, M.; Gallagher, M.M.; Malkki, M.; Petersdorf, E.; Dupont, B.; et al. HLA-C-dependent prevention of leukemia relapse by donor activating KIR2DS1. N. Engl. J. Med. 2012, 367, 805-816. [CrossRef]

131. Ciurea, S.O.; Al Malki, M.M.; Kongtim, P.; Fuchs, E.J.; Luznik, L.; Huang, X.J.; Ciceri, F.; Locatelli, F.; Aversa, F.; Castagna, L.; et al. The European Society for Blood and Marrow Transplantation (EBMT) consensus recommendations for donor selection in haploidentical hematopoietic cell transplantation. Bone Marrow Transplant. 2019. [CrossRef] [PubMed]

132. Miller, J.S.; Soignier, Y.; Panoskaltsis-Mortari, A.; McNearney, S.A.; Yun, G.H.; Fautsch, S.K.; McKenna, D.; Le, C.; Defor, T.E.; Burns, L.J.; et al. Successful adoptive transfer and in vivo expansion of human haploidentical NK cells in patients with cancer. Blood 2005, 105, 3051-3057. [CrossRef] [PubMed]

133. Cooley, S.; He, F.; Bachanova, V.; Vercellotti, G.M.; DeFor, T.E.; Curtsinger, J.M.; Robertson, P.; Grzywacz, B.; Conlon, K.C.; Waldmann, T.A.; et al. First-in-human trial of rhIL-15 and haploidentical natural killer cell therapy for advanced acute myeloid leukemia. Blood Adv. 2019, 3, 1970-1980. [CrossRef] [PubMed]

134. Rubnitz, J.E.; Inaba, H.; Ribeiro, R.C.; Pounds, S.; Rooney, B.; Bell, T.; Pui, C.H.; Leung, W. NKAML: A pilot study to determine the safety and feasibility of haploidentical natural killer cell transplantation in childhood acute myeloid leukemia. J. Clin. Oncol. 2010, 28, 955-959. [CrossRef] [PubMed]

135. Curti, A.; Ruggeri, L.; D’Addio, A.; Bontadini, A.; Dan, E.; Motta, M.R.; Trabanelli, S.; Giudice, V.; Urbani, E.; Martinelli, G.; et al. Successful transfer of alloreactive haploidentical KIR ligand-mismatched natural killer cells after infusion in elderly high risk acute myeloid leukemia patients. Blood 2011, 118, 3273-3279. [CrossRef] [PubMed]

136. Curti, A.; Ruggeri, L.; Parisi, S.; Bontadini, A.; Dan, E.; Motta, M.R.; Rizzi, S.; Trabanelli, S.; Ocadlikova, D.; Lecciso, M.; et al. Larger Size of Donor Alloreactive NK Cell Repertoire Correlates with Better Response to NK Cell Immunotherapy in Elderly Acute Myeloid Leukemia Patients. Clin. Cancer Res. 2016, 22, 1914-1921. [CrossRef]

137. Parisi, S.; Lecciso, M.; Ocadlikova, D.; Salvestrini, V.; Ciciarello, M.; Forte, D.; Corradi, G.; Cavo, M.; Curti, A. The More, The Better: "Do the Right Thing" For Natural Killer Immunotherapy in Acute Myeloid Leukemia. Front. Immunol. 2017, 8, 1330. [CrossRef]

138. Floros, T.; Tarhini, A.A. Anticancer Cytokines: Biology and Clinical Effects of Interferon- $\alpha 2$, Interleukin (IL)-2, IL-15, IL-21, and IL-12. Semin. Oncol. 2015, 42, 539-548. [CrossRef] 
139. Srivastava, S.; Pelloso, D.; Feng, H.; Voiles, L.; Lewis, D.; Haskova, Z.; Whitacre, M.; Trulli, S.; Chen, Y.J.; Toso, J.; et al. Effects of interleukin-18 on natural killer cells: Costimulation of activation through Fc receptors for immunoglobulin. Cancer Immunol. Immunother. 2013, 62, 1073-1082. [CrossRef]

140. Davis, Z.B.; Felices, M.; Verneris, M.R.; Miller, J.S. Natural Killer Cell Adoptive Transfer Therapy: Exploiting the First Line of Defense against Cancer. Cancer J. 2015, 21, 486-491. [CrossRef]

141. Hu, W.; Wang, G.; Huang, D.; Sui, M.; Xu, Y. Cancer Immunotherapy Based on Natural Killer Cells: Current Progress and New Opportunities. Front. Immunol. 2019, 10, 1205. [CrossRef] [PubMed]

142. Rosenberg, S.A.; Mule, J.J.; Spiess, P.J.; Reichert, C.M.; Schwarz, S.L. Regression of established pulmonary metastases and subcutaneous tumor mediated by the systemic administration of high-dose recombinant interleukin 2. J. Exp. Med. 1985, 161, 1169-1188. [CrossRef] [PubMed]

143. Delespine-Carmagnat, M.; Bouvier, G.; Bertoglio, J. Association of STAT1, STAT3 and STAT5 proteins with the IL-2 receptor involves different subdomains of the IL-2 receptor beta chain. Eur. J. Immunol. 2000, 30, 59-68. [CrossRef]

144. Kovanen, P.E.; Leonard, W.J. Cytokines and immunodeficiency diseases: Critical roles of the $\gamma(\mathrm{c})$-dependent cytokines interleukins 2, 4, 7, 9, 15, and 21, and their signaling pathways. Immunol. Rev. 2004, 202, 67-83. [CrossRef] [PubMed]

145. Rosenberg, S.A.; Lotze, M.T.; Muul, L.M.; Chang, A.E.; Avis, F.P.; Leitman, S.; Linehan, W.M.; Robertson, C.N.; Lee, R.E.; Rubin, J.T.; et al. A progress report on the treatment of 157 patients with advanced cancer using lymphokine-activated killer cells and interleukin-2 or high-dose interleukin-2 alone. N. Engl. J. Med. 1987, 316, 889-897. [CrossRef]

146. Dutcher, J.P.; Gaynor, E.R.; Boldt, D.H.; Doroshow, J.H.; Bar, M.H.; Sznol, M.; Mier, J.; Sparano, J.; Fisher, R.I.; Weiss, G.; et al. A phase II study of high-dose continuous infusion interleukin-2 with lymphokine-activated killer cells in patients with metastatic melanoma. J. Clin. Oncol. 1991, 9, 641-648. [CrossRef]

147. Chang, A.E.; Hyatt, C.L.; Rosenberg, S.A. Systemic administration of recombinant human interleukin-2 in mice. J. Biol. Response Mod. 1984, 3, 561-572.

148. Kruit, W.H.; Punt, C.J.; Goey, S.H.; de Mulder, P.H.; Gratama, J.W.; Eggermont, A.M.; Bolhuis, R.L.; Stoter, G. Dose efficacy study of two schedules of high-dose bolus administration of interleukin 2 and interferon $\alpha$ in metastatic melanoma. Br. J. Cancer 1996, 74, 951-955. [CrossRef]

149. Kruit, W.H.; Punt, K.J.; Goey, S.H.; de Mulder, P.H.; van Hoogenhuyze, D.C.; Henzen-Logmans, S.C.; Stoter, G. Cardiotoxicity as a dose-limiting factor in a schedule of high dose bolus therapy with interleukin-2 and $\alpha$-interferon. An unexpectedly frequent complication. Cancer 1994, 74, 2850-2856. [CrossRef]

150. Lotze, M.T.; Matory, Y.L.; Ettinghausen, S.E.; Rayner, A.A.; Sharrow, S.O.; Seipp, C.A.; Custer, M.C.; Rosenberg, S.A. In vivo administration of purified human interleukin 2. II. Half life, immunologic effects, and expansion of peripheral lymphoid cells in vivo with recombinant IL 2. J. Immunol. 1985, 135, 2865-2875.

151. Ghiringhelli, F.; Menard, C.; Terme, M.; Flament, C.; Taieb, J.; Chaput, N.; Puig, P.E.; Novault, S.; Escudier, B.; Vivier, E.; et al. CD4+CD25+ regulatory T cells inhibit natural killer cell functions in a transforming growth factor-beta-dependent manner. J. Exp. Med. 2005, 202, 1075-1085. [CrossRef] [PubMed]

152. Gasteiger, G.; Hemmers, S.; Firth, M.A.; Le Floc'h, A.; Huse, M.; Sun, J.C.; Rudensky, A.Y. IL-2-dependent tuning of NK cell sensitivity for target cells is controlled by regulatory T cells. J. Exp. Med. 2013, 210, 1167-1178. [CrossRef] [PubMed]

153. Sitrin, J.; Ring, A.; Garcia, K.C.; Benoist, C.; Mathis, D. Regulatory T cells control NK cells in an insulitic lesion by depriving them of IL-2. J. Exp. Med. 2013, 210, 1153-1165. [CrossRef]

154. Miller, J.S.; Tessmer-Tuck, J.; Pierson, B.A.; Weisdorf, D.; McGlave, P.; Blazar, B.R.; Katsanis, E.; Verfaillie, C.; Lebkowski, J.; Radford, J., Jr.; et al. Low dose subcutaneous interleukin-2 after autologous transplantation generates sustained in vivo natural killer cell activity. Biol. Blood Marrow Transplant. 1997, 3, 34-44.

155. Bachanova, V.; Burns, L.J.; McKenna, D.H.; Curtsinger, J.; Panoskaltsis-Mortari, A.; Lindgren, B.R.; Cooley, S.; Weisdorf, D.; Miller, J.S. Allogeneic natural killer cells for refractory lymphoma. Cancer Immunol. Immunother. 2010, 59, 1739-1744. [CrossRef] [PubMed]

156. Geller, M.A.; Miller, J.S. Use of allogeneic NK cells for cancer immunotherapy. Immunotherapy 2011, 3 , 1445-1459. [CrossRef] [PubMed]

157. Levin, A.M.; Bates, D.L.; Ring, A.M.; Krieg, C.; Lin, J.T.; Su, L.; Moraga, I.; Raeber, M.E.; Bowman, G.R.; Novick, P.; et al. Exploiting a natural conformational switch to engineer an interleukin-2 'superkine'. Nature 2012, 484, 529-533. [CrossRef] 
158. Sim, G.C.; Liu, C.; Wang, E.; Liu, H.; Creasy, C.; Dai, Z.; Overwijk, W.W.; Roszik, J.; Marincola, F.; Hwu, P.; et al. IL2 Variant Circumvents ICOS+ Regulatory T-cell Expansion and Promotes NK Cell Activation. Cancer Immunol. Res. 2016, 4, 983-994. [CrossRef]

159. Carmenate, T.; Pacios, A.; Enamorado, M.; Moreno, E.; Garcia-Martinez, K.; Fuente, D.; Leon, K. Human IL-2 mutein with higher antitumor efficacy than wild type IL-2. J. Immunol. 2013, 190, 6230-6238. [CrossRef]

160. Waldmann, T.A. The biology of interleukin-2 and interleukin-15: Implications for cancer therapy and vaccine design. Nat. Rev. Immunol. 2006, 6, 595-601. [CrossRef]

161. Grabstein, K.H.; Eisenman, J.; Shanebeck, K.; Rauch, C.; Srinivasan, S.; Fung, V.; Beers, C.; Richardson, J.; Schoenborn, M.A.; Ahdieh, M.; et al. Cloning of a T cell growth factor that interacts with the beta chain of the interleukin-2 receptor. Science 1994, 264, 965-968. [CrossRef] [PubMed]

162. Giri, J.G.; Kumaki, S.; Ahdieh, M.; Friend, D.J.; Loomis, A.; Shanebeck, K.; DuBose, R.; Cosman, D.; Park, L.S.; Anderson, D.M. Identification and cloning of a novel IL-15 binding protein that is structurally related to the $\alpha$ chain of the IL-2 receptor. EMBO J. 1995, 14, 3654-3663. [CrossRef] [PubMed]

163. Anderson, D.M.; Kumaki, S.; Ahdieh, M.; Bertles, J.; Tometsko, M.; Loomis, A.; Giri, J.; Copeland, N.G.; Gilbert, D.J.; Jenkins, N.A.; et al. Functional characterization of the human interleukin-15 receptor $\alpha$ chain and close linkage of IL15RA and IL2RA genes. J. Biol. Chem. 1995, 270, 29862-29869. [CrossRef] [PubMed]

164. Mortier, E.; Advincula, R.; Kim, L.; Chmura, S.; Barrera, J.; Reizis, B.; Malynn, B.A.; Ma, A. Macrophage- and dendritic-cell-derived interleukin-15 receptor alpha supports homeostasis of distinct CD8+ T cell subsets. Immunity 2009, 31, 811-822. [CrossRef]

165. Rubinstein, M.P.; Kovar, M.; Purton, J.F.; Cho, J.H.; Boyman, O.; Surh, C.D.; Sprent, J. Converting IL-15 to a superagonist by binding to soluble IL-15R $\{\alpha\}$. Proc. Natl. Acad. Sci. USA 2006, 103, 9166-9171. [CrossRef]

166. Wong, H.C.; Jeng, E.K.; Rhode, P.R. The IL-15-based superagonist ALT-803 promotes the antigen-independent conversion of memory CD8(+) T cells into innate-like effector cells with antitumor activity. Oncoimmunology 2013, 2, e26442. [CrossRef]

167. Han, K.P.; Zhu, X.; Liu, B.; Jeng, E.; Kong, L.; Yovandich, J.L.; Vyas, V.V.; Marcus, W.D.; Chavaillaz, P.A.; Romero, C.A.; et al. IL-15:IL-15 receptor alpha superagonist complex: High-level co-expression in recombinant mammalian cells, purification and characterization. Cytokine 2011, 56, 804-810. [CrossRef]

168. Romee, R.; Cooley, S.; Berrien-Elliott, M.M.; Westervelt, P.; Verneris, M.R.; Wagner, J.E.; Weisdorf, D.J.; Blazar, B.R.; Ustun, C.; DeFor, T.E.; et al. First-in-human phase 1 clinical study of the IL-15 superagonist complex ALT-803 to treat relapse after transplantation. Blood 2018, 131, 2515-2527. [CrossRef]

169. Liu, B.; Kong, L.; Han, K.; Hong, H.; Marcus, W.D.; Chen, X.; Jeng, E.K.; Alter, S.; Zhu, X.; Rubinstein, M.P.; et al. A Novel Fusion of ALT-803 (Interleukin (IL)-15 Superagonist) with an Antibody Demonstrates Antigen-specific Antitumor Responses. J. Biol. Chem. 2016, 291, 23869-23881. [CrossRef]

170. Wang, Y.; Zhang, Y.; Yi, P.; Dong, W.; Nalin, A.P.; Zhang, J.; Zhu, Z.; Chen, L.; Benson, D.M.; Mundy-Bosse, B.L.; et al. The IL-15-AKT-XBP1s signaling pathway contributes to effector functions and survival in human NK cells. Nat. Immunol. 2019, 20, 10-17. [CrossRef]

171. Ni, J.; Miller, M.; Stojanovic, A.; Garbi, N.; Cerwenka, A. Sustained effector function of IL-12/15/18-preactivated NK cells against established tumors. J. Exp. Med. 2012, 209, 2351-2365. [CrossRef] [PubMed]

172. Romee, R.; Schneider, S.E.; Leong, J.W.; Chase, J.M.; Keppel, C.R.; Sullivan, R.P.; Cooper, M.A.; Fehniger, T.A. Cytokine activation induces human memory-like NK cells. Blood 2012, 120, 4751-4760. [CrossRef] [PubMed]

173. Berrien-Elliott, M.M.; Wagner, J.A.; Fehniger, T.A. Human Cytokine-Induced Memory-Like Natural Killer Cells. J. Innate Immun. 2015, 7, 563-571. [CrossRef] [PubMed]

174. Terren, I.; Mikelez, I.; Odriozola, I.; Gredilla, A.; Gonzalez, J.; Orrantia, A.; Vitalle, J.; Zenarruzabeitia, O.; Borrego, F. Implication of Interleukin-12/15/18 and Ruxolitinib in the Phenotype, Proliferation, and Polyfunctionality of Human Cytokine-Preactivated Natural Killer Cells. Front. Immunol. 2018, 9, 737. [CrossRef] [PubMed]

175. Romee, R.; Rosario, M.; Berrien-Elliott, M.M.; Wagner, J.A.; Jewell, B.A.; Schappe, T.; Leong, J.W.; Abdel-Latif, S.; Schneider, S.E.; Willey, S.; et al. Cytokine-induced memory-like natural killer cells exhibit enhanced responses against myeloid leukemia. Sci. Transl. Med. 2016, 8, 357ra123. [CrossRef] [PubMed]

176. Kasaian, M.T.; Whitters, M.J.; Carter, L.L.; Lowe, L.D.; Jussif, J.M.; Deng, B.; Johnson, K.A.; Witek, J.S.; Senices, M.; Konz, R.F.; et al. IL-21 limits NK cell responses and promotes antigen-specific T cell activation: A mediator of the transition from innate to adaptive immunity. Immunity 2002, 16, 559-569. [CrossRef] 
177. Sivori, S.; Cantoni, C.; Parolini, S.; Marcenaro, E.; Conte, R.; Moretta, L.; Moretta, A. IL-21 induces both rapid maturation of human CD34+ cell precursors towards NK cells and acquisition of surface killer Ig-like receptors. Eur. J. Immunol. 2003, 33, 3439-3447. [CrossRef]

178. Watanabe, M.; Kono, K.; Kawaguchi, Y.; Mizukami, Y.; Mimura, K.; Maruyama, T.; Fujii, H. Interleukin-21 can efficiently restore impaired antibody-dependent cell-mediated cytotoxicity in patients with oesophageal squamous cell carcinoma. Br. J. Cancer 2010, 102, 520-529. [CrossRef]

179. Wagner, J.; Pfannenstiel, V.; Waldmann, A.; Bergs, J.W.J.; Brill, B.; Huenecke, S.; Klingebiel, T.; Rodel, F.; Buchholz, C.J.; Wels, W.S.; et al. A Two-Phase Expansion Protocol Combining Interleukin (IL)-15 and IL-21 Improves Natural Killer Cell Proliferation and Cytotoxicity against Rhabdomyosarcoma. Front. Immunol. 2017, 8, 676. [CrossRef]

180. Denman, C.J.; Senyukov, V.V.; Somanchi, S.S.; Phatarpekar, P.V.; Kopp, L.M.; Johnson, J.L.; Singh, H.; Hurton, L.; Maiti, S.N.; Huls, M.H.; et al. Membrane-bound IL-21 promotes sustained ex vivo proliferation of human natural killer cells. PLoS ONE 2012, 7, e30264. [CrossRef]

181. Lim, S.H.; Beers, S.A.; French, R.R.; Johnson, P.W.; Glennie, M.J.; Cragg, M.S. Anti-CD20 monoclonal antibodies: Historical and future perspectives. Haematologica 2010, 95, 135-143. [CrossRef] [PubMed]

182. Bornstein, G.G.; Queva, C.; Tabrizi, M.; van Abbema, A.; Chavez, C.; Wang, P.; Foord, O.; Ahluwalia, K.; Laing, N.; Raja, S.; et al. Development of a new fully human anti-CD20 monoclonal antibody for the treatment of B-cell malignancies. Investig. New Drugs 2010, 28, 561-574. [CrossRef] [PubMed]

183. Goede, V.; Fischer, K.; Busch, R.; Engelke, A.; Eichhorst, B.; Wendtner, C.M.; Chagorova, T.; de la Serna, J.; Dilhuydy, M.S.; Illmer, T.; et al. Obinutuzumab plus chlorambucil in patients with CLL and coexisting conditions. N. Engl. J. Med. 2014, 370, 1101-1110. [CrossRef] [PubMed]

184. Herter, S.; Herting, F.; Mundigl, O.; Waldhauer, I.; Weinzierl, T.; Fauti, T.; Muth, G.; Ziegler-Landesberger, D.; Van Puijenbroek, E.; Lang, S.; et al. Preclinical activity of the type II CD20 antibody GA101 (obinutuzumab) compared with rituximab and ofatumumab in vitro and in xenograft models. Mol. Cancer Ther. 2013, 12, 2031-2042. [CrossRef] [PubMed]

185. Terszowski, G.; Klein, C.; Stern, M. KIR/HLA interactions negatively affect rituximab- but not GA101 (obinutuzumab)-induced antibody-dependent cellular cytotoxicity. J. Immunol. 2014, 192, 5618-5624. [CrossRef]

186. Capuano, C.; Pighi, C.; Molfetta, R.; Paolini, R.; Battella, S.; Palmieri, G.; Giannini, G.; Belardinilli, F.; Santoni, A.; Galandrini, R. Obinutuzumab-mediated high-affinity ligation of Fc $\gamma$ RIIIA/CD16 primes NK cells for IFN $\gamma$ production. Oncoimmunology 2017, 6, e1290037. [CrossRef]

187. Cartron, G.; Dacheux, L.; Salles, G.; Solal-Celigny, P.; Bardos, P.; Colombat, P.; Watier, H. Therapeutic activity of humanized anti-CD20 monoclonal antibody and polymorphism in IgG Fc receptor Fc $\gamma$ RIIIa gene. Blood 2002, 99, 754-758. [CrossRef]

188. Veeramani, S.; Wang, S.Y.; Dahle, C.; Blackwell, S.; Jacobus, L.; Knutson, T.; Button, A.; Link, B.K.; Weiner, G.J. Rituximab infusion induces NK activation in lymphoma patients with the high-affinity CD16 polymorphism. Blood 2011, 118, 3347-3349. [CrossRef]

189. Koerner, S.P.; Andre, M.C.; Leibold, J.S.; Kousis, P.C.; Kubler, A.; Pal, M.; Haen, S.P.; Buhring, H.J.; Grosse-Hovest, L.; Jung, G.; et al. An Fc-optimized CD133 antibody for induction of NK cell reactivity against myeloid leukemia. Leukemia 2017, 31, 459-469. [CrossRef]

190. von Stackelberg, A.; Locatelli, F.; Zugmaier, G.; Handgretinger, R.; Trippett, T.M.; Rizzari, C.; Bader, P.; O'Brien, M.M.; Brethon, B.; Bhojwani, D.; et al. Phase I/Phase II Study of Blinatumomab in Pediatric Patients with Relapsed/Refractory Acute Lymphoblastic Leukemia. J. Clin. Oncol. 2016, 34, 4381-4389. [CrossRef]

191. Ribera, J.M. Efficacy and safety of bispecific T-cell engager blinatumomab and the potential to improve leukemia-free survival in B-cell acute lymphoblastic leukemia. Expert Rev. Hematol. 2017, 10, 1057-1067. [CrossRef] [PubMed]

192. Sun, L.L.; Ellerman, D.; Mathieu, M.; Hristopoulos, M.; Chen, X.; Li, Y.; Yan, X.; Clark, R.; Reyes, A.; Stefanich, E.; et al. Anti-CD20/CD3 T cell-dependent bispecific antibody for the treatment of B cell malignancies. Sci. Transl. Med. 2015, 7, 287ra270. [CrossRef] [PubMed]

193. Stein, A.; Franklin, J.L.; Chia, V.M.; Arrindell, D.; Kormany, W.; Wright, J.; Parson, M.; Amouzadeh, H.R.; Choudhry, J.; Joseph, G. Benefit-Risk Assessment of Blinatumomab in the Treatment of Relapsed/Refractory B-Cell Precursor Acute Lymphoblastic Leukemia. Drug Saf. 2019, 42, 587-601. [CrossRef] [PubMed] 
194. Moore, G.L.; Bautista, C.; Pong, E.; Nguyen, D.H.; Jacinto, J.; Eivazi, A.; Muchhal, U.S.; Karki, S.; Chu, S.Y.; Lazar, G.A. A novel bispecific antibody format enables simultaneous bivalent and monovalent co-engagement of distinct target antigens. MAbs 2011, 3, 546-557. [CrossRef]

195. Gleason, M.K.; Verneris, M.R.; Todhunter, D.A.; Zhang, B.; McCullar, V.; Zhou, S.X.; Panoskaltsis-Mortari, A.; Weiner, L.M.; Vallera, D.A.; Miller, J.S. Bispecific and Trispecific Killer Cell Engagers Directly Activate Human NK Cells through CD16 Signaling and Induce Cytotoxicity and Cytokine Production. Mol. Cancer Ther. 2012, 11, 2674-2684. [CrossRef]

196. Gleason, M.K.; Ross, J.A.; Warlick, E.D.; Lund, T.C.; Verneris, M.R.; Wiernik, A.; Spellman, S.; Haagenson, M.D.; Lenvik, A.J.; Litzow, M.R.; et al. CD16xCD33 bispecific killer cell engager (BiKE) activates NK cells against primary MDS and MDSC CD33+ targets. Blood 2014, 123, 3016-3026. [CrossRef]

197. Wiernik, A.; Foley, B.; Zhang, B.; Verneris, M.R.; Warlick, E.; Gleason, M.K.; Ross, J.A.; Luo, X.; Weisdorf, D.J.; Walcheck, B.; et al. Targeting natural killer cells to acute myeloid leukemia in vitro with a CD16 $\times 33$ bispecific killer cell engager and ADAM17 inhibition. Clin. Cancer Res. 2013, 19, 3844-3855. [CrossRef]

198. Vallera, D.A.; Felices, M.; McElmurry, R.; McCullar, V.; Zhou, X.; Schmohl, J.U.; Zhang, B.; Lenvik, A.J.; Panoskaltsis-Mortari, A.; Verneris, M.R.; et al. IL15 Trispecific Killer Engagers (TriKE) Make Natural Killer Cells Specific to CD33+ Targets While Also Inducing Persistence, In Vivo Expansion, and Enhanced Function. Clin. Cancer Res. 2016, 22, 3440-3450. [CrossRef]

199. Sarhan, D.; Brandt, L.; Felices, M.; Guldevall, K.; Lenvik, T.; Hinderlie, P.; Curtsinger, J.; Warlick, E.; Spellman, S.R.; Blazar, B.R.; et al. 161533 TriKE stimulates NK-cell function to overcome myeloid-derived suppressor cells in MDS. Blood Adv. 2018, 2, 1459-1469. [CrossRef]

200. Felices, M.; Kodal, B.; Hinderlie, P.; Kaminski, M.F.; Cooley, S.; Weisdorf, D.J.; Vallera, D.A.; Miller, J.S.; Bachanova, V. Novel CD19-targeted TriKE restores NK cell function and proliferative capacity in CLL. Blood Adv. 2019, 3, 897-907. [CrossRef]

201. Mejstríková, E.; Hrusak, O.; Borowitz, M.J.; Whitlock, J.A.; Brethon, B.; Trippett, T.M.; Zugmaier, G.; Gore, L.; von Stackelberg, A.; Locatelli, F. CD19-negative relapse of pediatric B-cell precursor acute lymphoblastic leukemia following blinatumomab treatment. Blood Cancer J. 2017, 7. [CrossRef] [PubMed]

202. Arvindam, U.S.; van Hauten, P.; Hallstrom, C.; Vallera, D.A.; Dolstra, H.; Miller, J.S.; Felices, M. CD16-IL15-CLEC12A Trispecific Killer Engager (TriKE) Drives NK Cell Expansion, Activation, and Antigen Specific Killing of Cancer Stem Cells in Acute Myeloid Leukemia. Blood 2018, 132, 1454. [CrossRef]

203. Ellwanger, K.; Reusch, U.; Fucek, I.; Wingert, S.; Ross, T.; Müller, T.; Schniegler-Mattox, U.; Haneke, T.; Rajkovic, E.; Koch, J.; et al. Redirected optimized cell killing $\left(\mathrm{ROCK}^{\circledR}\right)$ : A highly versatile multispecific fit-for-purpose antibody platform for engaging innate immunity. $m A b s$ 2019, 11, 899-918. [CrossRef] [PubMed]

204. Rothe, A.; Sasse, S.; Topp, M.S.; Eichenauer, D.A.; Hummel, H.; Reiners, K.S.; Dietlein, M.; Kuhnert, G.; Kessler, J.; Buerkle, C.; et al. A phase 1 study of the bispecific anti-CD30/CD16A antibody construct AFM13 in patients with relapsed or refractory Hodgkin lymphoma. Blood 2015, 125, 4024-4031. [CrossRef] [PubMed]

205. Guma, M.; Busch, L.K.; Salazar-Fontana, L.I.; Bellosillo, B.; Morte, C.; Garcia, P.; Lopez-Botet, M. The CD94/NKG2C killer lectin-like receptor constitutes an alternative activation pathway for a subset of CD8+ T cells. Eur. J. Immunol. 2005, 35, 2071-2080. [CrossRef]

206. Muntasell, A.; Vilches, C.; Angulo, A.; Lopez-Botet, M. Adaptive reconfiguration of the human NK-cell compartment in response to cytomegalovirus: A different perspective of the host-pathogen interaction. Eur. J. Immunol. 2013, 43, 1133-1141. [CrossRef]

207. Muccio, L.; Bertaina, A.; Falco, M.; Pende, D.; Meazza, R.; Lopez-Botet, M.; Moretta, L.; Locatelli, F.; Moretta, A.; Della Chiesa, M. Analysis of memory-like natural killer cells in human cytomegalovirus-infected children undergoing $\alpha \beta+\mathrm{T}$ and B cell-depleted hematopoietic stem cell transplantation for hematological malignancies. Haematologica 2016, 101, 371-381. [CrossRef]

208. Cichocki, F.; Cooley, S.; Davis, Z.; DeFor, T.E.; Schlums, H.; Zhang, B.; Brunstein, C.G.; Blazar, B.R.; Wagner, J.; Diamond, D.J.; et al. CD56dimCD57+NKG2C+ NK cell expansion is associated with reduced leukemia relapse after reduced intensity HCT. Leukemia 2016, 30, 456-463. [CrossRef]

209. Cichocki, F.; Taras, E.; Chiuppesi, F.; Wagner, J.E.; Blazar, B.R.; Brunstein, C.; Luo, X.; Diamond, D.J.; Cooley, S.; Weisdorf, D.J.; et al. Adaptive NK cell reconstitution is associated with better clinical outcomes. JCI Insight 2019, 4. [CrossRef] 
210. Schlums, H.; Cichocki, F.; Tesi, B.; Theorell, J.; Beziat, V.; Holmes, T.D.; Han, H.; Chiang, S.C.; Foley, B.; Mattsson, K.; et al. Cytomegalovirus infection drives adaptive epigenetic diversification of NK cells with altered signaling and effector function. Immunity 2015, 42, 443-456. [CrossRef]

211. Capuano, C.; Battella, S.; Pighi, C.; Franchitti, L.; Turriziani, O.; Morrone, S.; Santoni, A.; Galandrini, R.; Palmieri, G. Tumor-Targeting Anti-CD20 Antibodies Mediate In Vitro Expansion of Memory Natural Killer Cells: Impact of CD16 Affinity Ligation Conditions and In Vivo Priming. Front. Immunol. 2018, 9, 1031. [CrossRef] [PubMed]

212. Chiu, E.; Cichocki, F.; Felices, M.; Cooley, S.; Chu, H.; Ge, M.Q.; Bjordahl, R.; Kaufman, D.S.; Malmberg, K.-J.; Valamehr, B.; et al. Induced Pluripotent Stem Cell-Derived NK Cells Genetically Modified to Express NKG2C/DAP12 Mediate Potent Function When Targeted through an NKG2C/IL-15/CD33 Tri-Specific Killer Engager (TriKE). Blood 2018, 132, 729. [CrossRef]

213. Liu, L.L.; Beziat, V.; Oei, V.Y.S.; Pfefferle, A.; Schaffer, M.; Lehmann, S.; Hellstrom-Lindberg, E.; Soderhall, S.; Heyman, M.; Grander, D.; et al. Ex Vivo Expanded Adaptive NK Cells Effectively Kill Primary Acute Lymphoblastic Leukemia Cells. Cancer Immunol. Res. 2017, 5, 654-665. [CrossRef]

214. Gauthier, L.; Morel, A.; Anceriz, N.; Rossi, B.; Blanchard-Alvarez, A.; Grondin, G.; Trichard, S.; Cesari, C.; Sapet, M.; Bosco, F.; et al. Multifunctional Natural Killer Cell Engagers Targeting NKp46 Trigger Protective Tumor Immunity. Cell 2019, 177, 1701-1713 e1716. [CrossRef] [PubMed]

215. Romagne, F.; Andre, P.; Spee, P.; Zahn, S.; Anfossi, N.; Gauthier, L.; Capanni, M.; Ruggeri, L.; Benson, D.M., Jr.; Blaser, B.W.; et al. Preclinical characterization of 1-7F9, a novel human anti-KIR receptor therapeutic antibody that augments natural killer-mediated killing of tumor cells. Blood 2009, 114, 2667-2677. [CrossRef] [PubMed]

216. Vey, N.; Bourhis, J.H.; Boissel, N.; Bordessoule, D.; Prebet, T.; Charbonnier, A.; Etienne, A.; Andre, P.; Romagne, F.; Benson, D.; et al. A phase 1 trial of the anti-inhibitory KIR mAb IPH2101 for AML in complete remission. Blood 2012, 120, 4317-4323. [CrossRef]

217. Benson, D.M., Jr.; Hofmeister, C.C.; Padmanabhan, S.; Suvannasankha, A.; Jagannath, S.; Abonour, R.; Bakan, C.; Andre, P.; Efebera, Y.; Tiollier, J.; et al. A phase 1 trial of the anti-KIR antibody IPH2101 in patients with relapsed/refractory multiple myeloma. Blood 2012, 120, 4324-4333. [CrossRef]

218. Benson, D.M., Jr.; Cohen, A.D.; Jagannath, S.; Munshi, N.C.; Spitzer, G.; Hofmeister, C.C.; Efebera, Y.A.; Andre, P.; Zerbib, R.; Caligiuri, M.A. A Phase I Trial of the Anti-KIR Antibody IPH2101 and Lenalidomide in Patients with Relapsed/Refractory Multiple Myeloma. Clin. Cancer Res. 2015, 21, 4055-4061. [CrossRef]

219. Andre, P.; Denis, C.; Soulas, C.; Bourbon-Caillet, C.; Lopez, J.; Arnoux, T.; Blery, M.; Bonnafous, C.; Gauthier, L.; Morel, A.; et al. Anti-NKG2A mAb Is a Checkpoint Inhibitor that Promotes Anti-tumor Immunity by Unleashing Both T and NK Cells. Cell 2018, 175, 1731-1743. [CrossRef]

220. Maude, S.L.; Laetsch, T.W.; Buechner, J.; Rives, S.; Boyer, M.; Bittencourt, H.; Bader, P.; Verneris, M.R.; Stefanski, H.E.; Myers, G.D.; et al. Tisagenlecleucel in Children and Young Adults with B-Cell Lymphoblastic Leukemia. N. Engl. J. Med. 2018, 378, 439-448. [CrossRef]

221. Neelapu, S.S.; Locke, F.L.; Bartlett, N.L.; Lekakis, L.J.; Miklos, D.B.; Jacobson, C.A.; Braunschweig, I.; Oluwole, O.O.; Siddiqi, T.; Lin, Y.; et al. Axicabtagene Ciloleucel CAR T-Cell Therapy in Refractory Large B-Cell Lymphoma. N. Engl. J. Med. 2017, 377, 2531-2544. [CrossRef] [PubMed]

222. Park, J.H.; Riviere, I.; Gonen, M.; Wang, X.; Senechal, B.; Curran, K.J.; Sauter, C.; Wang, Y.; Santomasso, B.; Mead, E.; et al. Long-Term Follow-up of CD19 CAR Therapy in Acute Lymphoblastic Leukemia. N. Engl. J. Med. 2018, 378, 449-459. [CrossRef] [PubMed]

223. Daher, M.; Rezvani, K. Next generation natural killer cells for cancer immunotherapy: The promise of genetic engineering. Curr. Opin. Immunol. 2018, 51, 146-153. [CrossRef] [PubMed]

224. Moretta, L.; Locatelli, F.; Pende, D.; Sivori, S.; Falco, M.; Bottino, C.; Mingari, M.C.; Moretta, A. Human NK receptors: From the molecules to the therapy of high risk leukemias. FEBS Lett. 2011, 585, 1563-1567. [CrossRef] [PubMed]

225. Cooper, M.A.; Fehniger, T.A.; Caligiuri, M.A. The biology of human natural killer-cell subsets. Trends Immunol. 2001, 22, 633-640. [CrossRef]

226. Gong, J.H.; Maki, G.; Klingemann, H.G. Characterization of a human cell line (NK-92) with phenotypical and functional characteristics of activated natural killer cells. Leukemia 1994, 8, 652-658. [PubMed]

227. Mehta, R.S.; Rezvani, K. Chimeric Antigen Receptor Expressing Natural Killer Cells for the Immunotherapy of Cancer. Front. Immunol. 2018, 9, 283. [CrossRef] 
228. Li, Y.; Hermanson, D.L.; Moriarity, B.S.; Kaufman, D.S. Human iPSC-Derived Natural Killer Cells Engineered with Chimeric Antigen Receptors Enhance Anti-tumor Activity. Cell Stem Cell 2018, 23, 181-192. [CrossRef]

229. Saetersmoen, M.L.; Hammer, Q.; Valamehr, B.; Kaufman, D.S.; Malmberg, K.J. Off-the-shelf cell therapy with induced pluripotent stem cell-derived natural killer cells. Semin. Immunopathol. 2019, 41, 59-68. [CrossRef]

230. Tam, Y.K.; Martinson, J.A.; Doligosa, K.; Klingemann, H.G. Ex vivo expansion of the highly cytotoxic human natural killer-92 cell-line under current good manufacturing practice conditions for clinical adoptive cellular immunotherapy. Cytotherapy 2003, 5, 259-272. [CrossRef]

231. Tonn, T.; Schwabe, D.; Klingemann, H.G.; Becker, S.; Esser, R.; Koehl, U.; Suttorp, M.; Seifried, E.; Ottmann, O.G.; Bug, G. Treatment of patients with advanced cancer with the natural killer cell line NK-92. Cytotherapy 2013, 15, 1563-1570. [CrossRef] [PubMed]

232. Arai, S.; Meagher, R.; Swearingen, M.; Myint, H.; Rich, E.; Martinson, J.; Klingemann, H. Infusion of the allogeneic cell line NK-92 in patients with advanced renal cell cancer or melanoma: A phase I trial. Cytotherapy 2008, 10, 625-632. [CrossRef] [PubMed]

233. Romanski, A.; Uherek, C.; Bug, G.; Seifried, E.; Klingemann, H.; Wels, W.S.; Ottmann, O.G.; Tonn, T. CD19-CAR engineered NK-92 cells are sufficient to overcome NK cell resistance in B-cell malignancies. J. Cell. Mol. Med. 2016, 20, 1287-1294. [CrossRef] [PubMed]

234. Uherek, C.; Tonn, T.; Uherek, B.; Becker, S.; Schnierle, B.; Klingemann, H.G.; Wels, W. Retargeting of natural killer-cell cytolytic activity to ErbB2-expressing cancer cells results in efficient and selective tumor cell destruction. Blood 2002, 100, 1265-1273. [CrossRef]

235. Imai, C.; Iwamoto, S.; Campana, D. Genetic modification of primary natural killer cells overcomes inhibitory signals and induces specific killing of leukemic cells. Blood 2005, 106, 376-383. [CrossRef]

236. Muller, T.; Uherek, C.; Maki, G.; Chow, K.U.; Schimpf, A.; Klingemann, H.G.; Tonn, T.; Wels, W.S. Expression of a CD20-specific chimeric antigen receptor enhances cytotoxic activity of NK cells and overcomes NK-resistance of lymphoma and leukemia cells. Cancer Immunol. Immunother. 2008, 57, 411-423. [CrossRef]

237. Mihara, K.; Bhattacharyya, J.; Kitanaka, A.; Yanagihara, K.; Kubo, T.; Takei, Y.; Asaoku, H.; Takihara, Y.; Kimura, A. T-cell immunotherapy with a chimeric receptor against CD38 is effective in eliminating myeloma cells. Leukemia 2012, 26, 365-367. [CrossRef]

238. You, F.; Wang, Y.; Jiang, L.; Zhu, X.; Chen, D.; Yuan, L.; An, G.; Meng, H.; Yang, L. A novel CD7 chimeric antigen receptor-modified NK-92MI cell line targeting T-cell acute lymphoblastic leukemia. Am. J. Cancer Res. 2019, 9, 64-78.

239. Chen, K.H.; Wada, M.; Firor, A.E.; Pinz, K.G.; Jares, A.; Liu, H.; Salman, H.; Golightly, M.; Lan, F.; Jiang, X.; et al. Novel anti-CD3 chimeric antigen receptor targeting of aggressive T cell malignancies. Oncotarget 2016, 7, 56219-56232. [CrossRef]

240. Chen, K.H.; Wada, M.; Pinz, K.G.; Liu, H.; Lin, K.W.; Jares, A.; Firor, A.E.; Shuai, X.; Salman, H.; Golightly, M.; et al. Preclinical targeting of aggressive T-cell malignancies using anti-CD5 chimeric antigen receptor. Leukemia 2017, 31, 2151-2160. [CrossRef]

241. Esser, R.; Muller, T.; Stefes, D.; Kloess, S.; Seidel, D.; Gillies, S.D.; Aperlo-Iffland, C.; Huston, J.S.; Uherek, C.; Schonfeld, K.; et al. NK cells engineered to express a GD2 -specific antigen receptor display built-in ADCC-like activity against tumour cells of neuroectodermal origin. J. Cell. Mol. Med. 2012, 16, 569-581. [CrossRef] [PubMed]

242. Tassev, D.V.; Cheng, M.; Cheung, N.K. Retargeting NK92 cells using an HLA-A2-restricted, EBNA3C-specific chimeric antigen receptor. Cancer Gene Ther. 2012, 19, 84-100. [CrossRef] [PubMed]

243. Han, J.; Chu, J.; Keung Chan, W.; Zhang, J.; Wang, Y.; Cohen, J.B.; Victor, A.; Meisen, W.H.; Kim, S.H.; Grandi, P.; et al. CAR-Engineered NK Cells Targeting Wild-Type EGFR and EGFRvIII Enhance Killing of Glioblastoma and Patient-Derived Glioblastoma Stem Cells. Sci. Rep. 2015, 5, 11483. [CrossRef] [PubMed]

244. Sahm, C.; Schonfeld, K.; Wels, W.S. Expression of IL-15 in NK cells results in rapid enrichment and selective cytotoxicity of gene-modified effectors that carry a tumor-specific antigen receptor. Cancer Immunol. Immunother. 2012, 61, 1451-1461. [CrossRef] [PubMed]

245. Chu, J.; Deng, Y.; Benson, D.M.; He, S.; Hughes, T.; Zhang, J.; Peng, Y.; Mao, H.; Yi, L.; Ghoshal, K.; et al. CS1-specific chimeric antigen receptor (CAR)-engineered natural killer cells enhance in vitro and in vivo antitumor activity against human multiple myeloma. Leukemia 2014, 28, 917-927. [CrossRef] 
246. Tang, X.; Yang, L.; Li, Z.; Nalin, A.P.; Dai, H.; Xu, T.; Yin, J.; You, F.; Zhu, M.; Shen, W.; et al. First-in-man clinical trial of CAR NK-92 cells: Safety test of CD33-CAR NK-92 cells in patients with relapsed and refractory acute myeloid leukemia. Am. J. Cancer Res. 2018, 8, 1083-1089.

247. Kloess, S.; Oberschmidt, O.; Dahlke, J.; Vu, X.K.; Neudoerfl, C.; Kloos, A.; Gardlowski, T.; Matthies, N.; Heuser, M.; Meyer, J.; et al. Preclinical Assessment of Suitable Natural Killer Cell Sources for Chimeric Antigen Receptor Natural Killer-Based “Off-the-Shelf” Acute Myeloid Leukemia Immunotherapies. Hum. Gene Ther. 2019, 30, 381-401. [CrossRef]

248. Maki, G.; Klingemann, H.G.; Martinson, J.A.; Tam, Y.K. Factors regulating the cytotoxic activity of the human natural killer cell line, NK-92. J. Hematother. Stem Cell Res. 2001, 10, 369-383. [CrossRef]

249. Suck, G.; Odendahl, M.; Nowakowska, P.; Seidl, C.; Wels, W.S.; Klingemann, H.G.; Tonn, T. NK-92: An 'off-the-shelf therapeutic' for adoptive natural killer cell-based cancer immunotherapy. Cancer Immunol. Immunother. 2016, 65, 485-492. [CrossRef]

250. Sarvaria, A.; Jawdat, D.; Madrigal, J.A.; Saudemont, A. Umbilical Cord Blood Natural Killer Cells, Their Characteristics, and Potential Clinical Applications. Front. Immunol. 2017, 8, 329. [CrossRef]

251. Shah, N.; Martin-Antonio, B.; Yang, H.; Ku, S.; Lee, D.A.; Cooper, L.J.; Decker, W.K.; Li, S.; Robinson, S.N.; Sekine, T.; et al. Antigen presenting cell-mediated expansion of human umbilical cord blood yields log-scale expansion of natural killer cells with anti-myeloma activity. PLoS ONE 2013, 8, e76781. [CrossRef] [PubMed]

252. Ayello, J.; Hochberg, J.; Flower, A.; Chu, Y.; Baxi, L.V.; Quish, W.; van de Ven, C.; Cairo, M.S. Genetically re-engineered K562 cells significantly expand and functionally activate cord blood natural killer cells: Potential for adoptive cellular immunotherapy. Exp. Hematol. 2017, 46, 38-47. [CrossRef] [PubMed]

253. Liu, E.; Tong, Y.; Dotti, G.; Shaim, H.; Savoldo, B.; Mukherjee, M.; Orange, J.; Wan, X.; Lu, X.; Reynolds, A.; et al. Cord blood NK cells engineered to express IL-15 and a CD19-targeted CAR show long-term persistence and potent antitumor activity. Leukemia 2018, 32, 520-531. [CrossRef] [PubMed]

254. Iyengar, R.; Handgretinger, R.; Babarin-Dorner, A.; Leimig, T.; Otto, M.; Geiger, T.L.; Holladay, M.S.; Houston, J.; Leung, W. Purification of human natural killer cells using a clinical-scale immunomagnetic method. Cytotherapy 2003, 5, 479-484. [CrossRef]

255. Koehl, U.; Esser, R.; Zimmermann, S.; Tonn, T.; Kotchetkov, R.; Bartling, T.; Sorensen, J.; Gruttner, H.P.; Bader, P.; Seifried, E.; et al. Ex vivo expansion of highly purified NK cells for immunotherapy after haploidentical stem cell transplantation in children. Klinische Padiatrie 2005, 217, 345-350. [CrossRef]

256. Sutlu, T.; Stellan, B.; Gilljam, M.; Quezada, H.C.; Nahi, H.; Gahrton, G.; Alici, E. Clinical-grade, large-scale, feeder-free expansion of highly active human natural killer cells for adoptive immunotherapy using an automated bioreactor. Cytotherapy 2010, 12, 1044-1055. [CrossRef]

257. Leung, W. Use of NK cell activity in cure by transplant. Br. J. Haematol. 2011, 155, 14-29. [CrossRef]

258. Leung, W. Infusions of allogeneic natural killer cells as cancer therapy. Clin. Cancer Res. 2014, 20, 3390-3400. [CrossRef]

259. Kweon, S.; Phan, M.T.; Chun, S.; Yu, H.; Kim, J.; Kim, S.; Lee, J.; Ali, A.K.; Lee, S.H.; Kim, S.K.; et al. Expansion of Human NK Cells Using K562 Cells Expressing OX40 Ligand and Short Exposure to IL-21. Front. Immunol. 2019, 10, 879. [CrossRef]

260. Fujisaki, H.; Kakuda, H.; Shimasaki, N.; Imai, C.; Ma, J.; Lockey, T.; Eldridge, P.; Leung, W.H.; Campana, D. Expansion of highly cytotoxic human natural killer cells for cancer cell therapy. Cancer Res. 2009, 69, 4010-4017. [CrossRef]

261. Quintarelli, C.; Sivori, S.; Caruso, S.; Carlomagno, S.; Falco, M.; Boffa, I.; Orlando, D.; Guercio, M.; Abbaszadeh, Z.; Sinibaldi, M.; et al. Efficacy of third-party chimeric antigen receptor modified peripheral blood natural killer cells for adoptive cell therapy of B Cell Precursor Acute Lymphoblastic Leukemia. Leukemia 2019, in press.

262. De Oliveira, S.N.; Ryan, C.; Giannoni, F.; Hardee, C.L.; Tremcinska, I.; Katebian, B.; Wherley, J.; Sahaghian, A.; Tu, A.; Grogan, T.; et al. Modification of hematopoietic stem/progenitor cells with CD19-specific chimeric antigen receptors as a novel approach for cancer immunotherapy. Hum. Gene Ther. 2013, 24, 824-839. [CrossRef] [PubMed]

263. Guo, C.; Wang, X.; Zhang, H.; Zhi, L.; Lv, T.; Li, M.; Lu, C.; Zhu, W. Structure-based rational design of a novel chimeric PD1-NKG2D receptor for natural killer cells. Mol. Immunol. 2019, 114, 108-113. [CrossRef] [PubMed] 
264. Topfer, K.; Cartellieri, M.; Michen, S.; Wiedemuth, R.; Muller, N.; Lindemann, D.; Bachmann, M.; Fussel, M.; Schackert, G.; Temme, A. DAP12-based activating chimeric antigen receptor for NK cell tumor immunotherapy. J. Immunol. 2015, 194, 3201-3212. [CrossRef]

265. Xiao, L.; Cen, D.; Gan, H.; Sun, Y.; Huang, N.; Xiong, H.; Jin, Q.; Su, L.; Liu, X.; Wang, K.; et al. Adoptive Transfer of NKG2D CAR mRNA-Engineered Natural Killer Cells in Colorectal Cancer Patients. Mol. Ther. 2019, 27, 1114-1125. [CrossRef]

266. Ingegnere, T.; Mariotti, F.R.; Pelosi, A.; Quintarelli, C.; De Angelis, B.; Tumino, N.; Besi, F.; Cantoni, C.; Locatelli, F.; Vacca, P.; et al. Human CAR NK Cells: A New Non-viral Method Allowing High Efficient Transfection and Strong Tumor Cell Killing. Front. Immunol. 2019, 10, 957. [CrossRef]

267. Oberschmidt, O.; Morgan, M.; Huppert, V.; Kessler, J.; Gardlowski, T.; Matthies, N.; Aleksandrova, K.; Arseniev, L.; Schambach, A.; Koehl, U.; et al. Development of Automated Separation, Expansion, and Quality Control Protocols for Clinical-Scale Manufacturing of Primary Human NK Cells and Aretroviral Chimeric Antigen Receptor Engineering. Hum. Gene Ther. Methods 2019, 30, 102-120. [CrossRef]

268. Boissel, L.; Betancur, M.; Lu, W.; Wels, W.S.; Marino, T.; Van Etten, R.A.; Klingemann, H. Comparison of mRNA and lentiviral based transfection of natural killer cells with chimeric antigen receptors recognizing lymphoid antigens. Leuk Lymphoma 2012, 53, 958-965. [CrossRef]

269. Veerman, R.E.; Gucluler Akpinar, G.; Eldh, M.; Gabrielsson, S. Immune Cell-Derived Extracellular Vesicles-Functions and Therapeutic Applications. Trends Mol. Med. 2019, 25, 382-394. [CrossRef]

(C) 2019 by the authors. Licensee MDPI, Basel, Switzerland. This article is an open access article distributed under the terms and conditions of the Creative Commons Attribution (CC BY) license (http://creativecommons.org/licenses/by/4.0/). 